\title{
Lithic Technology \\ Cores, Core-Scrapers, and Bladelet Production during the Lower Magdalenian Occupations of El Mirón Cave, Cantabrian Spain

\author{
--Manuscript Draft--
}

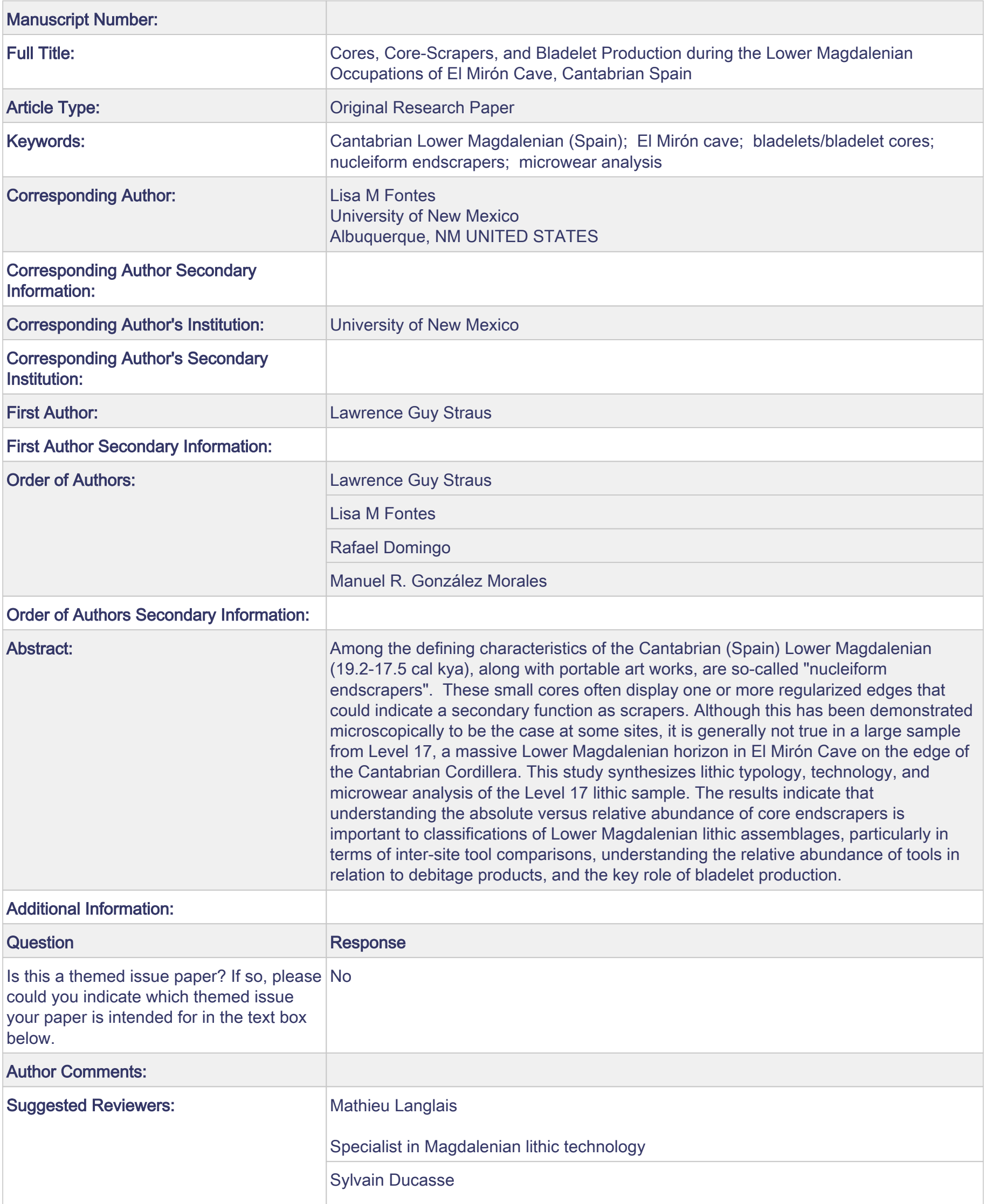


Specialist in Magdalenian lithic technology

Ted Goebel

Specialist in stone artifact analysis and microliths

Nuno Bicho

Specialist in Upper Paleolithic in Iberia 


\begin{abstract}
Among the defining characteristics of the Cantabrian (Spain) Lower Magdalenian (19.2-17.5 cal kya), along with portable art works, are so-called "nucleiform endscrapers". These small cores often display one or more regularized edges that could indicate a secondary function as scrapers. Although this has been demonstrated microscopically to be the case at some sites, it is generally not true in a large sample from Level 17, a massive Lower Magdalenian horizon in El Mirón Cave on the edge of the Cantabrian Cordillera. This study synthesizes lithic typology, technology, and microwear analysis of the Level 17 lithic sample. The results indicate that understanding the absolute versus relative abundance of core endscrapers is important to classifications of Lower Magdalenian lithic assemblages, particularly in terms of inter-site tool comparisons, understanding the relative abundance of tools in relation to debitage products, and the key role of bladelet production.
\end{abstract}




\section{Introduction}

The aim of this paper is to describe and discuss the bladelet (microblade)-rich lithic technology of the Lower Magdalenian human occupations of El Mirón Cave in comparison with other sites in Cantabria, Spain, with particular reference to the nature and functions of often very abundant, small cores and core-scrapers on excellent-quality, non-local flint that historically have been characterized as "hallmarks" of this distinctive regional cultural phase. Decades of archaeological research and debate have focused on the questions of the roles of microliths and so-called "nucleiform endscrapers" in the Lower Magdalenian, including opposing views on the function(s) of the latter: as only cores, or as cores reused as specialized miniature scrapers.

The Lower Magdalenian cultural phase in Cantabrian (northern Atlantic) Spain is dated between about 19.2-17.5 cal kya (González Sainz and Utrilla 2005), and took place immediately after the Last Glacial Maximum during Greenland Stadial 2 (early Oldest Dryas)(Clark et al. 2009). This $350 \mathrm{E}-\mathrm{W}$ km-long, 25-50 N-S km-wide region lies between the Bidasoa River in the east (at the western end of the Pyrenees and the modern border with France) and the Nalón River in the west (in central Asturias at the occidental end of the karstic limestone bedrock that makes the region rich in caves and thus abundant preserved Upper Paleolithic sites) (Fig. 1). It is tightly circumscribed by the Bay of Biscay to the north and the Cantabrian Cordillera to the south. Under glacial conditions, sea level regression created an additional 5-12 km of dry land along the narrow continental shelf, while ice sheets covered the Pyrenees and the highest peaks of the Cordillera, with especially large glaciers in the Picos de Europa (up to $2600 \mathrm{~m}$ a.s.1.) that still existed during Oldest Dryas times (Rodríguez et al. 2015; Serrano et al. 2015).

In the central sector of the Cantabrian geographic region-administratively Cantabria Province per se and western Asturias Province - the Lower Magdalenian has long been recognized archeologically as quite distinctive based on its material culture (e.g., González Echegaray 1960, 1971; Janssens and González Echegaray 1958; Jordá 1958, 1963; Utrilla 1981; see also Straus 1992). Key cave sites for the identification of a cultural phase between the Solutrean (with its invasively retouched lithic "leaf" points and shouldered points) and the Upper Magdalenian (with its antler harpoons) in Cantabria were El Castillo (discovered and first tested by H. Alcalde del Río in 1903 and then extensively excavated by H. Obermaier et al. between 1910-1014) and Altamira (discovered and first excavated by M. Sanz de Sautuola between 18761879 and further excavated by Alcalde del Río in1903-1906, Obermaier in 1924-1925, J.

González Echegaray and L.G. Freeman in 1981, and C. de las Heras et al. in 2008-2009) and El Juyo (excavated by P. Janssens and González Echegary in 1955-1957 and by González Echegaray and Freeman from 1978 discontinuously through the 1990s). La Lloseta (a.k.a. Cueva del Río) in eastern Asturias (excavated by Hernández Pacheco and P. Wernert in 1915 and F. Jordá in 1955-1956) and Cueto de la Mina (excavated by the Conde de la Vega del Sella in 1915) were key sites in the early definition of a Lower Magdalenian in eastern Asturias. E1 Rascaño (excavated by González Echegaray and I. Barandiarán with L.G. Straus in 1974), was a critical site in demonstrating that the so-called Magdalenian III of Cantabria was probably not the oldest post-Solutrean industry in this region. Here, the Lower Magdalenian was underlain by an Initial/Archaic Magdalenian, as is now also the case in El Mirón Cave in the next valley to the east of El Rascaño. Other Lower Magdalenian sites exist to the west (e.g., La Paloma) and east (e.g., Santimamiñe) of the central sector, but, although they share some characteristics of the classic Cantabrian Lower Magdalenian, they lack one of its most distinctive markers: striationengraved red deer scapulae with images of ungulates (mainly heads of red deer hinds). 
First discovered by Alcalde del Río in Altamira and then by Obermaier in El Castillo (both with numerous specimens), striation-engraved scapulae have subsequently been found in certain or probable Lower Magdalenian contexts in El Juyo, El Rascaño, El Pendo (all five being sites in central Cantabria Province in the Saja, Pas and Miera drainages) and in more peripheral sites: El Cierro (eastern Asturias) and El Mirón (eastern Cantabria) (Almagro 1976; González Morales and Straus 2009; González Morales et al. 2006; de las Heras et al. 2010, all with references). Radiocarbon dating on charcoal and bones from the levels that yielded such scapulae in Altamira and El Mirón and on scapulae themselves from Altamira have yielded results ranging from about 18.8-17.6 cal kya, while the four El Juyo specimens came from an undated level bracketed by dated levels that are in the same age range. In addition, there are similarly striated and virtually identical images of red deer hinds (and other ungulates) engraved on the walls of caves in the same central sector from eastern Asturias to eastern Cantabria (notably including Altamira and El Castillo), but also in outlier sites both to the west (Peña de Candamo in central Asturias) and east (Alkerdi in Guipúzcoa) (see Utrilla 2004). The scapulae (and the cave engravings) could arguably define an art style zone that might correspond to the territory of a regional forager group composed of local bands with smaller habitual-use territories comprised of river valleys, of which there are eight in the area defined by the presence of the engraved scapulae. The core of this possible regional band territory would seem to have been the adjacent valleys of the Pas/Pisueña and Saja/Besaya in central Cantabria Province, where the majority of these artifacts have been found.

The other artifact that is characteristic of the Cantabrian Lower Magdalenian (although not exclusively) is the so-called "nucleiform endscraper", tool type 15 on the original Upper Paleolithic type list of D. de Sonneville-Bordes and J. Perrot (1954: 332). It is defined simply as "an endscraper made on a core by regularization of the striking platform" (translation by LGS). It can be close in form to type 16, "rabot" or "plane", defined as "usually a prismatic core, sometimes a pyramidal core, reworked by regularization of a straight or convex striking platform, with a very oblique or even nearly vertical profile" (translation by LGS). Curiously, de Sonneville-Bordes and Perrot (quite exceptionally) provided no illustration of their type 15 (and only one of type 16 - a prismatic bladelet core). Problematic almost from the start, these two types were dropped from the later (but never formally published) revised version of the "Bordeaux" Upper Paleolithic typology (see Hemingway 1980). But the nucleiform endscraper type was particularly and enduringly prominent among Cantabrian Lower Magdalenian assemblages from the outset of systematic investigations, initially being called "goat's foot scrapers", or bulky or thick scrapers. Typically in Cantabrian assemblages these are small, conical cores from which bladelets and flakes have been removed to the point of "exhaustion" and one or more of whose (usually convex or straight) striking platform(s) display consistent, localized, contiguous nibbling retouch suggestive of edge regularization. Although many of these cores are "mixed", with both flake and bladelet removal scars, their standardized form and small size indicate that they were deliberately used for bladelet manufacture, since any small flake removals may not have been usable and were probably just debris, rather than projectile point cutting edges, barbs, or tips, which were mostly made on bladelet blanks. According to the analyses of P. Utrilla (1981), all endscrapers combined (including type 15 in highly varying percentages) tend to outnumber burins in assemblages from the classic Cantabrian Lower Magdalenian sites.

Some Cantabrian assemblages were recognized specifically to contain very high percentages of nucleiform scrapers, notably El Juyo (all of whose layers pertain to the Lower 
Magdalenian) (Janssens and González Echegaray 1958; González Echegaray 1971) with percentages of type 15 ranging 5-20\% from the old excavations (Utrilla 1981:314-315) and 2-6\% in preliminary counts from the fine-mesh, water-screened 1980s excavations (González Echegaray 1985); and La Lloseta in whose many Lower Magdalenian levels type 15 makes up 13-39\% (usually around 20-25\%) of the retouched artifacts (Utrilla 1981:308-310). In the classic, 1.5-2 m-thick (!) Magdalenian Beta horizon (Level 8) of Obermaier's excavation in El Castillo (probably a palimpsest of Initial and Lower Magdalenian occupations), type 15 makes up 16\% of an assemblage no doubt artificially poor in retouched/backed bladelets (Cabrera 1984:299). In the montane site of El Rascaño, modern excavations with water-screening yielded a staggering 52\% nucleiform scrapers from the Lower Magdalenian Level 4 (Utrilla 1981:316). In El Mirón Cave, with fine-mesh (1-2 mm) water-screening and hence large numbers of backed bladelets, nucleiform endscrapers make up 4-14\% of the tools among the spits of Lower Magdalenian Level 312 in the Mid-Vestibule Trench sondage P6 (Straus et al. 2008), 5\% of the assemblage from level 15 in the Outer Vestibule area, and 2\% of the Level 504 assemblage from the Burial Area at the Vestibule Rear, but only $0.8 \%$ from underlying Level 505 (Fontes et al. 2015). One interpretation by Utrilla (1984:171) was that the nucleiform endscrapers were not necessarily abandoned in the same sites where they had initial been used as cores to produce large numbers of flakes and bladelets, since she found in her dissertation study of the Cantabrian Lower Magdalenian (Utrilla 1981) that type 15 artifacts were not always accompanied in their final resting places by such vast quantities of these débitage products. (Collection and subsequent curation problems could be important factors especially for the old excavations that were studied.) Certainly, however, this was not always the case in the above-cited El Mirón assemblages: just among the retouched pieces, backed and retouched bladelets make up 44\% in Level 312, 8\% in Level 15, and 48\% in Level 504 and $46 \%$ in underlying Level 505 . The relationship between so-called nucleiform scrapers and retouched bladelets is apparently quite variable. Levels 504 and 505, the layers through and into which the human burial pit was dug in Lower Magdalenian times, yielded huge quantities of micro-débitage (trimming flakes and shatter measuring $<1 \mathrm{~cm}$ ) and unretouched bladelets: 26,941 and 985 respectively from Level 504 and 13,433 and 1,069 respectively from Level 505, while arguably "unmodified" cores (mostly bladelet and mixed flake-bladelet cores) are also abundant: 80 from Level 504 and 66 from Level 505. Only 3\% of the Level 504 and 6\% of the Level 505 assemblages are made up of unretouched bladelets (Fontes et al. 2015). The accidents of sampling different activity areas as they may have changed location from occupation to occupation within a cave by means of excavation pits at inevitably fixed positions clearly play important roles in the varying amounts and relative frequencies of different types of artifacts, as displayed by the disparate statistics cited above.

The scraping function of type 15 (and the so-called nucleiform burin-type 43) artifacts was called into question by L. Keeley (1988), based on microscopic analyses of samples of such items from El Juyo and El Rascaño: "there were a few cases of use on wood and hide" (p. 21), but $90 \%$ had traces of use as hammerstones or retouchers. This conclusion was countered in part by the dissertation work of C. Mazo. Most recently, Domingo, Mazo and Utrilla (2012) conducted a new microwear study of different artifacts from El Rascaño. They found that, while the small conical "nucleiform scrapers" from the Upper and Initial Magdalenian levels were very rarely used, many from the Lower Magdalenian level were in fact used to scrape bone (antler) and wood (but not hide). 
In the following analyses we will focus on the cores and so-called nucleiform scrapers (and planes), their function(s), and their relationship with the production of bladelets and flakes in the major Lower Magdalenian horizon of Level 17 in the $9.5 \mathrm{~m}^{2}$ Outer Vestibule excavation area of El Mirón Cave.

\section{El Mirón Outer Vestibule Level 17}

The principal Lower Magdalenian horizon in El Mirón Cave (Ramales, Cantabria) excavated by the project directed by Straus and González Morales (2012; Straus et al. 2015) between 1996-2013 is Level 17 in the $9.5 \mathrm{~m}^{2}$ Outer Vestibule Area, the "Cabin". Overlain by two other Lower Magdalenian levels dated to ca. 18-18.2 cal kya (Levels 15 and 16 - the latter of which intergrades substantially with 17 in sedimentological as well as archeological characteristics), Level 17 is $30-50 \mathrm{~cm}$ thick and was dug in 13-23 (av.=18) spits. Each spit was thus on average about $2 \mathrm{~cm}$ thick - the thickness of a deer or ibex long bone and less than the thickness of a cobble. The stratigraphy in the Cabin area is essentially horizontal, so the "living" surfaces could be "dissected" quite credibly, especially as there were several hearths (Nakazawa et al. 2009) and areas "paved" with fire-cracked rocks and cobbles throughout this palimpsest stratum. Long bones, elongated artifacts and cobbles lie flat on the surfaces. The lithic artifacts and faunal remains (dominated by red deer and ibex, with abundant salmon remains) are being analyzed (by L. Fontes and J.M. Geiling, respectively) by subdivisions of this horizon, in order to be able to discover and interpret changes through time in technological and subsistence activities in this part of the cave. Level 17 is dated by five radiocarbon assays between ca. 18.818.5 , but the (all very similar) dates are not in stratigraphic order, suggesting that the stratum was formed quite quickly--not surprising given its highly anthropogenic content (bones, lithic and osseous artifacts, manuports, charcoal, ochre). Underlying Lower Magdalenian Level 18 dates to ca. 19.3 cal kya. Level 17 is closely contemporary with the human burial at the rear of the El Mirón vestibule (18.7 cal kya). It is slightly younger than Level 312 in the Mid-Vestibule Trench (19.9 cal kya) and it is likely to be roughly contemporary with Level 109 in the Inner Vestibule excavation area immediately west (in the direction of the cave mouth) of the burial area and from which it is separated by a very large engraved and ochre-stained roof-fall block (Straus and González Morales 2007, 2010; Straus et al. 2015). Level 17 yielded a large stag scapula engraved with the image of a hind head typically "shaded" with fine striations plus the outline of an aurochs head (González Morales et al. 2006; González Morales and Straus 2009). The level is also characterized by a rich osseous industry, including many quadrangular section antler points, several with elaborate, geometric engraved designs. The combined lithic assemblages of Level 17 are summarized in Tables 1 (knapping debris) and 2 (retouched tools). The vast majority of both debris and tools is on non-local flints of excellent quality, but small nodule or blank size. Many of the flints (various shades of solid or banded gray, fine-grain, homogeneous) are probably from the vast Upper Cretaceous flysch outcrops at Barrika on the Holocene shore between the mouth of the Nervión River near Bilbao and the town of Plentzia in eastern Vizcaya (see description in Tarriño 2006). Other flints may be from sources along the present-day eastern shore of Cantabria at Sonabia and Llaranza (see Rissetto 2009) or perhaps flysch outcrops now undersea. Additionally, some trans-cordilleran flints (Treviño and Urbasa) and "exotic" flints from southern France (Bidache and Chalosse) have been identified in the El Mirón assemblages. There are also substantial quantities of items of débitage, cores and tools (mainly "macroliths" such as sidescrapers, denticulates and notches) that are on quartzite, limestone and mudstone that are available either in the cave or in the beds of the rivers directly below the site. 


\section{The Aggregate Lithic Artifact Assemblage of Level 17}

Straus and Fontes have studied the cores and so-called "nucleiform endscrapers" (and "planes") of Level 17. The analyses have involved determination of raw materials, dimensions, numbers and types of removal scars (flake, blade and bladelet), core type (globular/amorphous, pyramidal [conical], prismatic, core-on-flake), polarity of removals (uni- or bi-polar), evidence of "regularization" of striking platforms ["scraper retouch"]). These detailed analyses followed more general classification of the whole lithic assemblages (usually done yearly at the close of each excavation season by members of the project team under supervision by Straus). For the latter work, the retouched tool typology of de Sonneville-Bordes and Perrot, a lithic debris/ débitage typology developed over many years by G.A. Clark and Straus (see Straus and González Morales 2012: 354-355), and a large, ad hoc lithic raw material comparative collection were employed. Fontes added many refinements to the latter two systems during her detailed dissertation study of Lower Magdalenian assemblages not only from E1 Mirón Level 17, but also from other levels and sites in the Cantabrian region. Bladelets are defined as removals that are $\geq$ twice as long as they are wide, parallel sided, and $\leq 2 \mathrm{~cm}$ long. Such a short defining dimension for bladelets has been used here because, in contrast to many regions of France where flint nodules can be very large thus permitting the production of very long blades, flint nodules in Cantabria are generally very small and very long laminar products rare. Were we to use the $5 \mathrm{~cm}$ cut-off criterion for bladelet length common in France, there would be virtually no "blades" in Cantabrian assemblages and virtually all elongated removals would be called bladelets (a.k.a., lamellar products).

The complete lithic artifact assemblage from Level 17 is immense: 162,090 items of debris (cores and debitage) and 5,353 retouched tools (Tables 1 and 2). This assemblage is being analyzed in great detail by 13 thinner sub-levels (closer to actual "living floors"), by Fontes, but here we provide a preliminary summary of the whole, with a particular focus on the central importance of bladelet cores, bladelets (unretouched and retouched) and so-called nucleiform endscrapers in the lithic technology of this massive palimpsest of Lower Magdalenian occupation layers. The complete classification of the debris is presented in Table 1 and the tools in Table 2. In both tables the items are not only classified by morphological type, but for those artifacts $\geq 1 \mathrm{~cm}$ in length, also by lithic raw material type. The flint types are classified by likely sources, as defined by the work of J.J. Elorza and colleagues (1989), P. Sarabia (1991), J. Rissetto (2009), A. Tarriño (2006) and L. Fontes. All (or at least the vast majority) of the flints are non-local, as survey in the area around El Mirón has revealed only small amounts of poorquality vein and nodular flint in the Lower Cretaceous limestone bedrock of the drainage basins of the upper Asón valley and those of its tributaries, the Carranza, Calera and Gándara rivers. The main local raw materials used for making artifacts (as determined by prospection) include mudstone, limestone, quartz and quartzite - commonly found in the riverbeds below the site). The non-local sources of excellent-quality flint range in distance from about $26 \mathrm{~km}$ for Sonabia, $45 \mathrm{~km}$ for Llaranza and (most importantly) $65 \mathrm{~km}$ for Barrika--all Upper Cretaceous flysch outcrops along the present day cliffs along the coast of eastern Cantabria and western Vizcaya-to at least $200 \mathrm{~km}$ for the Chalosse sites in the lower Adour valley and the Bidache source in the Gaves Réunis valley of extreme SW France. The distances are intermediate to the Urbasa and Treviño sources (respectively ca. 115 and $130 \mathrm{~km}$ ), but these are on the southern side of the Cantabrian Cordillera, thus entailing far more difficult walks than along the then-exposed, albeit narrow, continental shelf of the Cantabrian shore north of the Cordillera, either west toward the 
area of modern Santander or west toward modern Bilbao and beyond to the area of modern Bayonne (Fig 1). Small numbers of flints may come from the area of the vast Ojo Guareña karstic system in northern Burgos, about $40 \mathrm{~km}$ southwest of El Mirón via $920 \mathrm{~m}$ Los Tornos Pass (possibly skirting the edge of a mountain glacier). The closer flints may have been obtained through direct procurement during the course of Mirón band seasonal subsistence rounds, while the distant ones may have been obtained either via down-the-line (band-to-band) trade and/or during individual visits by band members.

The Level 17 lithic debris assemblage includes 128,371 items of microdebitage (trimming flakes and angular shatter, all $<1 \mathrm{~cm}$ in length), representing 39.2\%. We did not attempt to classify these artifacts by raw material. There are 15,975 flakes $(\geq 1 \mathrm{~cm})$ of various types: $9.9 \%, 1447$ blades: $0.9 \%, 9,372$ bladelets: 5.8\%, 3806 chunks (large angular debris, including core fragments): $2.3 \%, 981$ splintered pieces (possible bipolar cores): $0.4 \%, 1,133$ cores: $0.7 \%, 981$ burin spalls (some of which might actually be simple, but thick bladelets): $0.4 \%$, plus 383 crested blades and platform renewal flakes: $0.2 \%$. The vast amounts of microdebitage, the presence of many cortical microdebitage items, flakes, blades and bladelets, crested blades, platform renewal flakes, and the large numbers of cores, splintered pieces and chunks (over half of which have some cortex) all indicate that knapping took place at El Mirón. In particular, cores with all or some bladelet removal scars $(n=604)$ make up $0.4 \%$ of the total assemblage and $53.3 \%$ of the group of cores per se. The production of bladelets was clearly a major activity at the site in the Lower Magdalenian.

Of the unretouched bladelets, 3,326 (35.5\%) are made of flints from Barrika, Llaranza or Sonabia--sources within reasonable distances from El Mirón along the present shore as noted above (Fig. 1). Flints of unknown sources, which could include other "coastal" flysch outcrops, add another 525 bladelets (5.6\%). Other flints from the known and more distant sources in SW France or in the trans-Cordilleran Basque Country/Navarra number 770 (8.2\%). The remaining bladelets are distributed among a variety of non-flint raw materials, none of which individually includes many bladelets. Fully $72.7 \%$ of the bladelet (and partly bladelet) cores are on Barrika, Llaranza or Sonabia flints, while unknown flints make up $11.4 \%(n=63)$. Small numbers of these cores are from the very distant sources, and none are on non-flint materials. Splintered pieces (often classified as chunks in the preliminary field classifying sessions) are overwhelmingly $(\mathrm{n}=423,70.0 \%)$ made on Barrika, Llaranza, or Sonabia flints and another $11.4 \%$ are on unknown flints, with small numbers of distant source materials. In contrast, although there are many Barrika flint flakes $(20.6 \%), 22.6 \%$ of the flakes are made on non-flint materials, with the rest mainly being from Sonabia and Llaranza. The only "significant" numbers of nonflint cores are flake cores on mudstone $(n=14)$ and quartzite $(n=13)$, plus 64 on unknown stones. In short, flintknappers who occupied El Mirón during the Lower Magdalenian strongly focused their activities on bladelet production and used flints from the coastal zone Upper Cretaceous outcrops to make these blanks. Their secondary focus was on flake production, both using highquality flints and local non-flints, especially quartzites and mudstones.

The main groups in the retouched tool assemblage can be summarized as follows: 616 endscrapers $(11.5 \%$ of the total assemblage -359 (58.1\% of the scrapers) of which are so-called nucleiform endscrapers (including one type 16 "plane"); 285 perforators (5.3\%); 364 burins (6.8\%) — of which 192 are simple burins-on-break; 381 continuously retouched pieces (7.1\%); 684 denticulates and notches (12,7\%); 519 splintered pieces (counted among both the debris and the tools, and possibly bipolar cores)(9.7\%); and1,393 backed and retouched bladelets (26.0\%). The bladelet tool percentage is intermediate between the high percentages (44-48\%) for levels 
504, 505 and 312 and the low one for Level 15, suggesting some functional variation, perhaps related to the importance of "rearming" activities during the different occupations and among the different activity areas represented by the respective excavation areas. Among the less wellrepresented types in Level 17, there are 99 truncated pieces (1.8\%), 60 sidescrapers (1.1\%), and 95 backed micropoints (1.8\%). Other notable types represented in very small quantities are two unifacial points and two fragments of bifacial leaf points--presumably Solutrean items picked up by Magdalenian people. There are 13 items classified as raclettes, which are supposedly typical of the Badegoulian (post-Solutrean/pre-Lower Magdalenian). Also noteworthy are 51 geometric microliths $(0.95 \%)$, something that is characteristic of the Cantabrian Lower Magdalenian. At issue in this paper is the question of so-called "nucleiform endscrapers"; if these are removed from the category of endscrapers (i.e., if they are only cores that were not re-used as scrapers), then the endscraper index would be only 4.8 - less than the burin index as opposed to being greater than it. Exclusion of type 15 here and conceivably in other Cantabrian Lower Magdalenian lithic assemblages would considerably change the endscraper/burin ratio in favor of the latter, although burins are generally very simply burins-on-break.

Virtually all the classic Upper Paleolithic tool types ("real" endscrapers, perforators, burins, truncated or backed blades and bladelets) are made on flint-mostly from the coastal zone sources at moderate distances from El Mirón (Barrika, Llaranza and Sonabia), but also small numbers of pieces from distant SW French and trans-Cordilleran sources. Specifically $70.7 \%$ of the type 15 "nucleiform endscrapers" are on "intermediate-distance" flints (and another $7.0 \%$ are on "other" flints from unknown sources. The simple backed bladelets (type 85 ) include $38.8 \%$ Barrika flint, $11.9 \%$ Llaranza flint, $7.2 \%$ Sonabia flints and $13.3 \%$ unidentified flints. In contrast, although flints are very important raw materials for non-classic Upper Paleolithic tool types, $3.6 \%$ of the continuously retouched pieces (types $65+66$ ) are on mudstone and quartzite (and $9.7 \%$ are on unidentified stones), $12.9 \%$ of the denticulates and notches are on those two non-flint materials (and 5.0\% are on unidentified stones). Over a fifth $(21.7 \%)$ of the sidescrapers are on non-flint materials. Lower Magdalenian stone tool makers clearly preferred excellent-quality flint for the manufacture of blades, bladelets, bladelet cores, and classic Upper Paleolithic tools. On the other hand, for large, "archaic" ("Middle Paleolithic") types of tools (generally made on flakes), they often turned to local non-flint raw materials, as these were quite sufficient (or perhaps in some cases superior to flint) for their functions.

\section{The Cores and Nucleiform Endscrapers of Level 17}

Straus conducted a detailed attribute analysis of about half (c. $700=47 \%$ ) of cores and items classified as nucleiform endscrapers from Level 17 (all called "cores" here) and Fontes refined the source information on the flint types used to make all these artifacts (samples are pictured in Figs. 2-6). The operative defining characteristic of nucleiform scrapers is the presence of one or more convex or straight core platform edges continuously regularized with fine retouching. Generally the artifacts in question have other platform edges that are not regularized, and indeed lack any retouching scars. A summary of the results is given in Table 3 . Fully $62.6 \%$ of the studied cores are made on semi-local/regional flints from the present day coast of eastern Cantabria and western Vizcaya (Barrika, Llaranza and Sonabia). In contrast, $7.0 \%$ are from trans-cordilleran sources (Urbasa, Treviño, Ojo Guareña), $4.6 \%$ are from sources in Gascony (Bidache and the various outcrops in Chalosse), and 10.6\% are from unknown flint sources. Aside from the flint cores, there are $5.9 \%$ of the items that are made on non-flints (a very few on mudstone and quartzite, and nearly three dozen on other, unidentified stones). 
There is a clear difference in average size between the flint cores and those made on other (non-flint) stones (Table 3). Average core lengths among the various flint types range between 22-26 $\mathrm{mm}$ (Barrika and Sonabia flint type cores both average $24 \mathrm{~mm}$.). On the other hand, quartzite, mudstone and other non-flint cores average 59, 39 and $35 \mathrm{~mm}$. in length respectively. Flint core average widths range between $17-19 \mathrm{~mm}$, while quartzite and mudstone averages are 51 and $31 \mathrm{~mm}$ respectively. Thickness averages for flint cores range between 12-14 $\mathrm{mm}$, while quartzite and mudstone ones are 33 and $21 \mathrm{~mm}$ respectively. The flint cores are almost all very small, yet $42.0 \%$ of the regional coastal zone flint items still bear some cortex after considerable reduction, indicating that the original nodules were already very small before they were used to (near-) exhaustion for the production of bladelets and flakes. In contrast, $34.6 \%$ of the distant-source flints have some cortex, as do $32.4 \%$ of the unidentified flint cores, suggesting that, as is logical, these rare nodules were even more reduced than the more local materials.

Among the flint cores, 241 are unipolar, 145 bipolar and 190 multipolar (Table 3). Among all the cores (flint and non-flint), 604 exhibit bladelet scars, 644 have flake scars, and 551 have both flake and bladelet scars. (There is only one core with a blade scar, i.e., $>2 \mathrm{~cm}$ long.) There are 113 cores with 1-3 bladelet removal scars, 69 with 4-7 and 5 with 8-10. There are 95 cores with 1-3 flake scars, 98 with 4-7, 12 with 8-10 and 1 with 14-16. The production of small bladelets was clearly a major focus of flint reduction in El Mirón during the Lower Magdalenian occupations of Level 17.

Eighty-four cores exhibit some edge-regularization, while only one mudstone core has this modification and 16 cores on unidentified stones have regularized edges. Fifty-seven of the cores studied in this sample were labeled as nucleiform endscrapers (tool type 15) and only one of these is on mudstone and 9 are on unidentified stones. The small, flint nucleiform endscrapers fit perfectly into the regional type long described by Spanish archeologists for the classic Cantabrian Lower Magdalenian and sometimes called "pata de cabra"/"goat foot" scrapers.

\section{Functional Analysis of Nucleiform Endscrapers}

Domingo microscopically analyzed a sample of 101 so-called nucleiform endscrapers from El Mirón Level 17. Although this is a large sample and one that is judged to be representative, it still only represents slightly more than a quarter $(28.2 \%)$ of the total number of these artifacts from this extraordinarily rich palimpsest horizon.

As the diagnostic attributes used for functional classification (Domingo 2005a), we mainly used microscopic traces (micro-polish, striations, abrasion platforms, etc.), although we also took into consideration marks that are observable to the naked eye (chips, fissures, edgerounding, etc.). The collection was studied in the microscope laboratory of the Instituto Internacional de Investigaciones Prehistóricas at the Universidad de Cantabria (Santander) using a Leica DM 2500M metallographic microscope with 50x-500x power. The usual power range employed for observing micro-wear traces was 50x-200x.

In general the sample was composed of small artifacts with similar dimensions and compact shapes: on average about $23 \mathrm{~mm}$ long by $18 \mathrm{~mm}$ wide by $14 \mathrm{~mm}$ thick. More than $90 \%$ of the pieces are $\leq 30 \mathrm{~mm}$ in length and the same is true for their widths (98 of the 101 measure less than $30 \mathrm{~mm}$ ) and thicknesses, all of which are less than $30 \mathrm{~mm}$.

The studied pieces are curated in individual closed plastic bags and were not directly marked, since there are labels in the bags. Following the protocols outlined in Domingo (2005a, 
2009), Domingo classified the quality of his microscopic observations as "good", "acceptable", or "poor". To do this he used criteria that were logically subjective, including relative judgement of the lithic raw material grain size (coarse-grain materials are more poorly visible under the microscope), color (light tones reflect the microscope too much), presence of patina, soil polish, or thermal alteration, etc. Of the total of 101 items analyzed, 29 presented good observation characteristics, 32 acceptable and 40 poor. In our experience (Domingo 2005b, 2005c, 2009; Alvarez et al. n.d.), these proportions are relatively normal among sites from northern Spain, namely the upper Ebro valley and the Cantabrian coast, although they can vary in special cases, such as in Aizpea rockshelter (Basque Country), where the lithic artifacts are heavily altered by fire, which obviously is detrimental to microscopic observation (Domingo 2005b).

The results obtained with microscopic inspection are conclusive as to the function of the objects in question (Table 4): in all observable cases with microscopic traces the artifacts were simply cores, which, based on their morphologies, were used mainly to produce bladelets. The most frequent traces are those resulting from percussion (70 cases) - mainly with hard stone hammer--although occasionally we were able to identify marks made by soft hammers-wood or deer antler - and in a few cases it was impossible to determine which type of hammer had been used. Other traces caused by the use of these artifacts as cores are fissures in areas near the edge of the striking platform (11 cases). These fissures appear as a consequence of failed blows which do not lead to extractions for various reasons: insufficient impact force, incorrect placement of the point of percussion — generally too far from the platform edge - or excessive toughness of the raw material. Two other items display microscopic traces of edge abrasion done to regularize the angle between the striking and flaking planes with a view toward future extractions.

A few pieces display several types of microscopic traces. In some cases they complement one another in confirming the proposed functional interpretation, although in a very few other cases they suggest a secondary function that we can qualify as peremptory and occasional. Of the 59 "nucleiform endscrapers" with traces of hard hammer percussion, 6 also have fissures which indicate failed blows and another item also has traces of edge abrasion which confirm its apparently exclusive use as a bladelet core. One of the items with soft hammer traces also displays fissures from failed strikes.

As concerns any functions different from those as simply bladelet cores, in only three cases could Domingo identify microscopic traces that indicate strictly expedient utilitarian uses, namely to use "whatever is at hand". In these three cases, two with traces of hard hammer use and the third with traces from a hammer of indeterminate material, people took advantage of their morphology to use them for scraping tasks. The traces indicate that the materials scraped were bone, probably antler and green wood respectively (Figs. 7 and 8), although in the last of these cases a large removal near the edge makes it difficult to interpret the use-history of this core.

Metallic marks occasionally appear in prehistoric artifact collections - always derived from archeological activities: on the one hand during excavation with metal tools and on the other--mainly in the cases of old excavations - the use of metal pen nibs to label the artifacts. The latter possibility does not exist in the case of El Mirón, as the artifacts are unlabeled. Traces caused by the rubbing of excavation tools against artifacts are generally spread randomly across any surfaces of the lithic items. In a few of the El Mirón nucleiform endscrapers these metallic marks seem to be associated with impact striations related to bladelet extraction (Fig. 9), such that in principle we can entertain the hypothesis that some of the hammers used on these cores 
were fragments of metallic minerals such as pyrite or marcasite, both abundant in the Cantabrian region.

Could these traces imply that some of the "nucleiform endscrapers" were used to make fire? Cases of such flint and iron mineral (especially marcasite) strike-a-lights are not rare in European prehistory (Sorensen et al. 2014). Insofar as concerns the metallic traces found in E1 Mirón, R. Seva (personal communication, 2015) indicates that some of the metallic traces found on the lithic artifact surfaces could be pyrites, although microanalyses would be necessary to convincingly confirm this hypothesis. A.C. Sorensen (personal communication, 2016), based on the images of the cores in question, thinks that the traces are too "fresh" (i.e., there are no signs of oxidation) and could be the result of occasional contact with excavation tools, despite their association with prehistoric striations. One of the items with metallic traces was, however, collected after the excavators switched (after June 2004) from using metal tools to using wooden ones. Future work will include microanalysis of the metallic traces on some of the artifacts to either confirm or deny their antiquity (Lombardo et al. 2016), something that we cannot determine in the present work.

In conclusion, the relatively large analyzed sample appears to be made up of cores used to produce bladelets. Only occasionally were certain items also used for other purposes, and then never intensively. In some cases items were used expediently because they had forms that were apt in functioning as hammerstones, although they (as originally bladelet cores) had not been designed as such. In a nearby, similar chrono-cultural context at El Rascaño Cave, which Domingo also analyzed (Domingo et al. 2012), there is a very high percentage of small nucleiform endscrapers from classic Lower Magdalenian Level 4 with wear traces, while underlying Level 5 (Archaic Magdalenian), virtually none of these artifacts displaces traces of having been used as scrapers. The materials worked with these artifacts in Level 4 were exclusively bone or wood, but never hide. The abundance of hunting weapons (antler points) in Rascaño Level 4 led us to propose that these nucleiform endscrapers had produced bladelet inserts to arm composite projectile tips, and then were systematically re-used in making or repairing antler or wooden point shafts. But this was not the case in El Cierro Cave (eastern Asturias) (Álvarez-Fernández et al. n.d.), where the use of the nucleiform endscrapers was only occasional and unsystematic, as in El Mirón Level 17. This, in fact, is the general picture that exists normally among other Upper Paleolithic and Mesolithic sites throughout Europe where microwear studies have been done on such carinated artifacts. Dumont (1988) and Vaughan (1983), for example, found virtually no wear-traces on these artifacts from Star Carr and Cassegros respectively. LeBrun-Ricalens et al. (2006) conclude that the majority of carinated pieces (so-called nucleiform endscrapers and burins) are simply cores - not tools - according to their microwear analyses. Thus we find that El Mirón Level 17 displays a pattern like that found in many other European sites with respect to this class of artifact, which, at least here, were merely bladelet cores with only very occasional secondary uses.

\section{Conclusions}

Bladelet production (in addition to flakes - either deliberately or as incidental byproducts of the bladelet-making process), was a significant activity during the many Lower Magdalenian-age human occupations of El Mirón cave. These were almost exclusively struck from cores of excellent-quality, non-local flints (mainly sub-regional Upper Cretaceous materials from outcrops along the present coast - notably Barrika in western Vizcaya), but also a few trans-cordilleran and southern Aquitaine materials. Many of the bladelets were vertically 
retouched (dulled on one edge or truncated) to transform them into the disposable cutting edge (backed bladelet) and tip (backed micro-point) elements of composite projectile points. They were probably hafted on antler sagaies that are very abundant in Level 17, as in many Cantabrian Lower Magdalenian assemblages. These artifacts are often grooved for insertion of bladelets. In the case of El Mirón Level 17 a large sample of the many (basically) bladelet cores with regularized edges that would be classified as nucleiform endscrapers are shown here microscopically not to have been used for scraping, although in other cases some of the type 15 artifacts were demonstrably tools. Elimination of nearly 360 type 15 artifacts from the formal, retouched tool portion of the Level 17 lithic assemblage sharply reduces both the size of the tool fraction overall and specifically the relative importance of endscrapers. Nucleiform "endscrapers"-lumped together with artifacts classified as small bladelet cores - still make up one of the characteristics (albeit non-exclusive) of the Cantabrian Lower Magdalenian, but in those assemblages, like that of El Mirón Level 17, where they were not habitually re-used for scraping, the character and functional interpretations of the site occupations need to be reevaluated. What is clear-whether the small cores were secondarily utilized for scraping or not - is that bladelet production was a key, and no doubt critical activity at many Cantabrian Lower Magdalenian sites. Acquisition of the best-possible flint raw materials--albeit in small nodule sizes — constituted a vital aspect of forager mobility and/or social (i.e., trade) relations.

\section{Acknowledgements}

The El Mirón Prehistoric Project, co-directed by Straus and González Morales since 1996, has been authorized and partially funded by the Gobierno de Cantabria, with additional grants from the National Science Foundation, Fundación M. Botín, National Geographic Society, Ministerio de Educación y Ciencia, L.S.B. Leakey Foundation, University of New Mexico, Fund for Stone Age Resarch (J. and R. Auel, principal donors) and material support from the IIIPC Universidad de Cantabria and Town of Ramales de la Victoria. Fontes' research was funded by: the National Science Foundation Doctoral Dissertation Improvement Grant (\#1318485), the University of New Mexico Latin American and Iberian Institute Ph.D. fellowship, and an American Association for University Women American Dissertation fellowship. R. Domingo is a "Ramón y Cajal researcher (Ministerio de Economía y Competitividad, \#RyC2013-12613.

\section{References cited}

Álvarez-Fernández, E., D. Álvarez-Alonso, J. Bécares, P.Carral, R.P. Carriol, A. Chauvin, M. Cubas, M. Cueto, R. Domingo, J. Douka, J.F. Jordá, X. Murelaga, R. Portero, O.Rivero, J. Tapia, A. Tarriño, L.C. Teira

In press Nouvelles données sur le Magdalénien inférieur de la Région Cantabrique: le Niveau F de la grotte de El Cierro (Ribadesella, Asturies, Espagne). L'Anthropologie.

Almagro, M.

1976 Los omóplatos decorados de la Cueva de 'El Castillo'. Trabajos de Prehistoria 33:999.

Cabrera, V.

1984 El Yacimiento de la Cueva de 'El Castillo'. Bibliotheca Praehistorica Hispana 22, Madrid. 
Clark, P.U., A. Dyke, J. Shakun, A. Carlson, J. Clark, B. Wohlfarth, J. Mitrovica, S. Hostetler, A.M. McCabe

2009 The Last Glacial Maximum. Science 325:710-713.

Domingo, R.

2005a La funcionalidad de los microlitos geométricos. Bases experimentales para su estudio. Monografías Arqueológicas 41. Universidad de Zaragoza.

Domingo, R.

2005b Análisis funcional de los microlitos geométricos de Aizpea (Arive, Navarra).Veleia, 22: 27-50.

Domingo, R.

2005c Análisis funcional de los microlitos geométricos y láminas de Mendandia. En Alday, A. (ed.). El campamento prehistórico de Mendandia. Fundación José Miguel de Barandiarán, pp. 321-333.

Domingo, R.

2009 Caracterización funcional de los microlitos geométricos. El caso del Valle del Ebro. In Utrilla, P. and Montes, L. (eds.) El Mesolítico geométrico en la Península Ibérica. Monografías Arqueologícas 44. Universidad de Zaragoza, pp. 375-390.

Domingo, R., C. Mazo, and P. Utrilla

2012 Hunting camps and nucleiform endscrapers in the Cantabrian Lower Magdalenian: a lithic microwear analysis. In: The Magdalenian Settlement of Europe, edited by L.G. Straus, T. Terberger, and B. Eriksen, pp. 105-110. Quaternary International 272-273.

Dumont, J.V.

1988 A microwear analysis of selected artefact types from the Mesolithic sites of Star Carr and Mount Sandel, Oxford.

Fontes, L.M., L.G. Straus, and M.R. González Morales

2015 Lithic and osseous artifacts from the Lower Magdalenian human burial deposit in El Mirón Cave, Cantabria, Spain. In: The Red Lady of El Mirón Cave, edited by L.G. Straus, M.R. González Morales, and J.M. Carretero, pp. 99-111. Journal of Archaeological Science 60.

Fontes, L.M., L.G. Straus, and M.R. González Morales

In press Lithic Raw Material Conveyance and Hunter-Gatherer Mobility during the Lower Magdalenian period in Cantabria, Spain. In press by Quaternary International. DOI: http://dx.doi.org/10.1016/j.quaint.2015.09.017 
González Echegaray, J.

1960 El Magdaleniense III de la Costa Cantábrica. Boletín del Seminario de Arte y Arqueología (Universidad de Valladolid)26:1-32.

1971 Apreciacionescuantitativassobre el Magdaleniense III de la Costa Cantábrica. Munibe 23:323-327.

1985 La industrialítica. In Excavaciones en la Cueva del Juyo, edited by I. Barandiarán, L.G. Freeman, J. González Echegaray, and R.G. Klein, pp. 121-153. Monografías, Centro de Investigación y Museo de Altamira, No. 14, Madrid.

González Morales, M.R., and L.G. Straus

2009 Extraordinary Early Magdalenian finds from El Mirón Cave, Cantabria (Spain). Antiquity 83:267-281.

González Morales, M.R., L.G. Straus, and A.B. Marín

2006 Los omóplatos decorados magdalenienses de la Cueva del Mirón y su relación con las cuevas del Castillo, Altamira y El Juyo. In: Miscelánea en Homenaje a Victoria Cabrera, edited by J.M. Maillo and E. Baquedano, vol. I, pp. 482-494. Zona Arqueológica 7, Museo Regional de Arqueología, Alcala de Henares.

González Sainz, C., and P. Utrilla

2004 Problemas actuales en la organización y datación del Magdaleniense de la región cantábrica. In: $O$ Paleolítico, edited by N. Bicho, pp. 39-47. Promontoria Monográfica 2, Faro.

Hemingway, $\mathrm{M}$.

1980 The Initial Magdalenian in France. British Archaeological Reports S-90, Oxford.

Heras, C. de las, J.A. Lasheras, P. Rasines, R. Montes, P. Fatás, A. Prada, and E. Muñoz 2012 Datation et contexte archéologique de la nouvelle omoplate gravée découverte à Altamira. In: L'Art Pléistocène dans le Monde, edited by J. Clottes, pp. 270-271, CD 1571-1588.

Janssens, P., and J. González Echegaray

1958 Memoria de las Excavaciones de la Cueva del Juyo (1955-56).Patronato de las Cuevas Prehistóricas, Santander.

Jordá, F.

1958 Avance al Estudio de la Cueva de la Lloseta. Diputación Provincial, Oviedo.

1963 El Paleolítico superior cantábrico y susindustrias.Saitabi13:3-22.

Keeley, L.

1988 Lithic economy, style and use: a comparison of three late Magdalenian sites. Lithic Technology 17:19-25. 
Le Brun-Ricalens, F., J.P. Bracco, J. P., L. Brou

2006 Burins carénés, grattoirs carénnés et forms associés: un retournement! In: Agraujo, M., Bracco, J.P. and Le Brun- Ricalens, F., (eds.), Burins préhistoriques: formes, fonctionnements, fonctions. Musée National d'histoireet d'art, Luxembourg, p. 345-356.

Lombardo, T., D. Grolimund, A. Kienholz, V. Hubert, M. Wörle

2016 The use of flint-stone fragments as "fire-strikers" during the Neolithic period:

Complementary micro-analytical evidences. Microchemical journal 125: 254-259.

Nakazawa, Y., L.G. Straus, M. González Morales, D. Cuenca, and J. Caro

2009 On stone-boiling technology in the Upper Paleolithic; behavioral implications from an early Magdalenian hearth in El Mirón, Cantabria, Spain. Journal of Archaeological Science 36:684-693.

Rissetto, J.

2009 Late Pleistocene Hunter-Gatherer Mobility Patterns and Lithic Exploitation in Eastern Cantabria (Spain). Unpublished Ph.D. dissertation, University of New Mexico.

Rodríguez, I., M. Jiménez, M. Domínguez, and A. Aranburu

2015 Research history on glacial geomorphology of the Cantabrian Mountains, north Iberia. In: Quaternary of the Western Pyrenees, edited by A. Cearreta, C. de la Rua, and M. García, pp.6-21. Quaternary International 364.

Sarabia, P.

1991 Approche de l'etude de la distribution stratigraphique du silex de la province de Cantabria (Espagne du Nord). In Le silex de sa genese à l'outil, eds. M.R. Séronie-Vivien and M. Lenoir, pp. 141-148. Cahiers du Quaternaire 17.

Serrano, E., M. Gómez, M.J. González, M. González, J. González, R. Pellitero, and I. Rico 2015 Glacial chronology, environmental changes and implications for human occupation during the Upper Pleistocene in the eastern Cantabrian Mountains. In: Quaternary of the Western Pyrenean Region, edited by A. Cearreta, C. de la Rua, and M. García, pp. 22-34. Quaternary International 364.

Sonneville-Bordes, D. de, Perrot, J.

1954 Lexique typologique du Paléolithique supérieur . Outillage lithique. I: Grattoirs, II. Outils solutréens. Bulletin de la Société Préhistorique Française 51:327-335.

Sorensen, A. C, A. van Gijn

2014 Fire production in the deep past? The expedient strike-a-light model. Journal of Archaeological Science 42: 476-486.

Straus, L.G.

1992 Iberia before the Iberians.University of New Mexico Press, Albuquerque. 
Straus, L.G., and M.R. González Morales

2007 Further radiocarbon dates for the Upper Paleolithic of El Mirón Cave. Radiocarbon 49:1205-1214.

2010 The radiocarbon chronology of El Mirón Cave: new dates for the Initial Magdalenian occupations. Radiocarbon 52:33-39.

2012 El Mirón Cave, Cantabrian Spain. University of New Mexico Press, Albuquerque.

Straus, L.G., M.R. González Morales, and J.M. Carretero (editors)

2015 The Red Lady of El Mirón Cave: Lower Magdalenian Human Burial in Cantabrian Spain. Journal of Archaeological Science 60 (Special Issue).

Straus, L.G., M.R. González Morales, and E. Stewart

2008 Early Magdalenian variability: new evidence from El Mirón Cave, Cantabria, Spain. Journal of Field Archaeology 33:197-218, 367-369.

Tarriño, A.

2006 El Sílex en la Cuenca Vasco-Cantábrica y Pireneo Navarro.Monografías, Museo Nacional y Centro de Investigación de Altamira, No. 21, Madrid.

Utrilla,P.

1981 El Magdaleniense Inferior y Medio en la Costa Cantábrica .Monografías, Centro de Investigación y Museo de Altamira No.4, Santander.

1984 ¿Es un útil el raspador nucleiforme? In Primeras Jornadas de Metodología de Investigación Prehistórica, Soria 1981, pp. 169-174. Ministerio de Cultura, Madrid.

2004 Evolución histórica de las sociedades cantábricas durante el Tardiglacial: el Magdaleniense inicial, inferior y medio. In: Las Sociedades del Paleolítico en la Región Cantábrica, edited by M. Fano, pp. 243-274. Kobie Anejo 8, Bilbao.

Vaughan, P. C.

1983 Use-Wear Analysis of Flaked Stone Tools. Tucson.

\section{Figure Captions}

Fig. 1. Map of Vasco-Cantabrian Spain and Southern France, indicating El Mirón cave and major lithic outcrops in the region. Lithic sources are numbered as follows: 1, Llaranza; 2, Ojo Guareña; 3, Sonabia; 4, Barrika; 5, Treviño; 6, Urbasa; 7, Bidache; and 8, Chalosse. Outcrop locations are approximate.

Fig. 2. Cores from El Mirón Level 17. Top left: Square J4 \#2020, patinated Llaranza flint. Top right: Square J4 \#2007, raw material indeterminable. Bottom left: Square I4 \#3642, whitish 
variety of Barrika flint. Bottom right: Square H2 \#2830, variety of flint Group F (see Fontes et al. in press). Photographs by M.R. González Morales.

Fig. 3. Cores from El Mirón Level 17. Top left: Square J4 \#2039, patinated Chalosse flint with calcium carbonate coating. Top right: Square H4 \#1937, made on whitish variety of Barrika flint and with calcium carbonate coating. Bottom left: Square H2 \#1510, patinated Llaranza flint. Bottom right: Square I4 \#3664, patinated Llaranza flint. Photographs by M.R. González Morales.

Fig. 4. Cores from El Mirón Level 17. Top left: Square J4 \#2213, Barrika flint. Bottom left: Square J4 \#2133, Barrika flint with calcium carbonate coating. Top right: Square J4 \#1738, patinated Sonabia flint with calcium carbonate coating. Middle right: Square J4 \#2176, patinated Sonabia flint. Bottom right: Square J4 \#2020, patinated Llaranza flint. Photographs by M.R. González Morales.

Fig. 5. Cores from El Mirón Level 17. Top: Square I4 \#2499, Barrika flint. Bottom: Square H2 \#133.12, made on Sonabia flint and with minute traces of calcium carbonate coating. Photographs by M.R. González Morales.

Fig. 6. Core from El Mirón Level 17. Square H2 \#2945, made on mudstone/lutite M1 (see Fontes et al. in press). Photographs by M.R. González Morales.

Fig. 7. Traces of bladelet removal by a hard hammer percussor.

Fig. 8. Traces of green wood scraping.

Fig. 9. Metallic marks associated with striations caused by removal of bladelets with a hard hammer percussor. 
Table 1. Lithic Debris Types and Counts by Raw Material Type.

Geographically known lithic toolstones are abbreviated as follows: Barrika (BAR), Bidache (BID), Chalosse (CHAL), Llaranza (LLAR), Ojo Guareña (OJO), Sonabia (SON), Treviño (TREV), and Urbasa (URB). All other lithic toolstones are abbreviated as follows: other flints (OF), limestones (LIME),

lutites/mudstones (MUD), quartzes and calcites (QC), quartzite (QTZ), other toolstones (OTHER), unknown stones (UNK) and microdebitage (MD).

\begin{tabular}{|c|c|c|c|c|c|c|c|c|c|c|c|c|c|c|c|c|c|}
\hline Debris Type & $\begin{array}{l}\text { Level } 17 \\
\text { Total }\end{array}$ & BAR & BID & CHAL & LLAR & OJO & SON & TREV & URB & OF & LIME & MUD & QC & QTZ & OTHER & UNK & MD \\
\hline $\begin{array}{l}\text { Non cortical } \\
\text { trimming flake }\end{array}$ & 104236 & -- & -- & -- & -- & -- & -- & -- & -- & -- & -- & -- & -- & -- & -- & -- & 104236 \\
\hline $\begin{array}{l}\text { Cortical trimming } \\
\text { flake }\end{array}$ & 5205 & -- & -- & -- & -- & -- & -- & -- & -- & -- & -- & -- & -- & -- & -- & -- & 5205 \\
\hline Non cortical shatter & 12338 & -- & -- & -- & -- & -- & -- & -- & -- & -- & -- & -- & -- & -- & -- & -- & 12338 \\
\hline Cortical shatter & 6593 & -- & -- & -- & -- & -- & -- & -- & -- & -- & -- & -- & -- & -- & -- & -- & 6593 \\
\hline Plain flake & 8012 & 1823 & 114 & 203 & 1054 & 26 & 1210 & 118 & 147 & 1016 & 32 & 77 & 21 & 98 & 17 & 2056 & -- \\
\hline $\begin{array}{l}\text { Fragmentary plain } \\
\text { flake }\end{array}$ & 2045 & 529 & 44 & 95 & 368 & 14 & 469 & 44 & 64 & 255 & 3 & 36 & 3 & 51 & 8 & 62 & -- \\
\hline $\begin{array}{l}\text { Primary decortication } \\
\text { flake }\end{array}$ & 513 & 156 & 10 & 11 & 43 & -- & 65 & 3 & 5 & 47 & 8 & 14 & -- & 43 & 1 & 107 & -- \\
\hline $\begin{array}{l}\text { Secondary } \\
\text { decortication flake }\end{array}$ & 3993 & 1174 & 27 & 143 & 600 & 10 & 688 & 47 & 128 & 371 & 18 & 211 & 2 & 187 & 26 & 361 & -- \\
\hline $\begin{array}{l}\text { Fragmentary cortical } \\
\text { flake }\end{array}$ & 1412 & 400 & 8 & 63 & 243 & 2 & 294 & 30 & 69 & 134 & 5 & 56 & 1 & 63 & 18 & 26 & -- \\
\hline Plain blade & 641 & 211 & 14 & 14 & 68 & 2 & 97 & 15 & 15 & 91 & 1 & 4 & 1 & 4 & -- & 104 & -- \\
\hline $\begin{array}{l}\text { Fragmentary plain } \\
\text { blade }\end{array}$ & 202 & 61 & 3 & 8 & 24 & 2 & 32 & 3 & 1 & 36 & -- & 2 & -- & 3 & -- & 27 & -- \\
\hline $\begin{array}{l}\text { Primary decortication } \\
\text { blade }\end{array}$ & 35 & 12 & -- & 1 & -- & -- & 6 & -- & -- & 9 & -- & 1 & -- & 1 & -- & 5 & -- \\
\hline $\begin{array}{l}\text { Secondary } \\
\text { decortication blade }\end{array}$ & 375 & 100 & 2 & 9 & 37 & 2 & 57 & 5 & 9 & 37 & 2 & 7 & -- & 12 & 1 & 95 & -- \\
\hline $\begin{array}{l}\text { Fragmentary cortical } \\
\text { blade }\end{array}$ & 194 & 34 & 1 & 2 & 7 & -- & 18 & 2 & 2 & 13 & -- & 1 & -- & 2 & 1 & 111 & -- \\
\hline Plain bladelet & 4793 & 843 & 32 & 93 & 314 & 6 & 399 & 53 & 62 & 365 & -- & 3 & 1 & 6 & 1 & 2615 & -- \\
\hline $\begin{array}{l}\text { Fragmentary plain } \\
\text { bladelet }\end{array}$ & 3869 & 754 & 17 & 93 & 240 & 9 & 404 & 33 & 62 & 327 & -- & 2 & 8 & 3 & 1 & 1916 & -- \\
\hline $\begin{array}{l}\text { Primary decortication } \\
\text { bladelet }\end{array}$ & 6 & 4 & -- & -- & 1 & -- & -- & -- & -- & 1 & -- & -- & -- & -- & -- & -- & -- \\
\hline $\begin{array}{l}\text { Secondary } \\
\text { decortication bladelet }\end{array}$ & 484 & 147 & -- & 24 & 51 & 1 & 64 & 3 & 21 & 50 & -- & -- & -- & 1 & -- & 122 & -- \\
\hline $\begin{array}{l}\text { Fragmentary } \\
\text { decortication bladelet }\end{array}$ & 220 & 56 & 1 & 4 & 17 & -- & 32 & 3 & 8 & 27 & 1 & -- & -- & -- & 1 & 70 & -- \\
\hline
\end{tabular}




\begin{tabular}{|c|c|c|c|c|c|c|c|c|c|c|c|c|c|c|c|c|c|}
\hline Non cortical chunk & 1725 & 438 & 21 & 22 & 181 & 4 & 248 & 17 & 21 & 221 & 9 & 17 & 77 & 11 & 8 & 430 & -- \\
\hline Cortical chunk & 2081 & 546 & 14 & 44 & 337 & 3 & 347 & 20 & 56 & 207 & 3 & 28 & 70 & 41 & 15 & 350 & -- \\
\hline Microburin & 17 & 11 & -- & -- & 3 & -- & -- & 1 & -- & 2 & -- & -- & -- & -- & -- & -- & -- \\
\hline Burin spall & 981 & 327 & 10 & 27 & 115 & 3 & 163 & 12 & 46 & 100 & 1 & 4 & 1 & 1 & -- & 171 & -- \\
\hline $\begin{array}{l}\text { Unidirectional } \\
\text { crested blade }\end{array}$ & 66 & 20 & 1 & 2 & 10 & -- & 13 & -- & 4 & 4 & -- & -- & -- & 1 & -- & 11 & -- \\
\hline $\begin{array}{l}\text { Bidirectional crested } \\
\text { blade }\end{array}$ & 23 & 8 & -- & -- & -- & -- & 5 & -- & -- & 3 & -- & -- & -- & -- & -- & 7 & -- \\
\hline $\begin{array}{l}\text { Platform renewal } \\
\text { flake }\end{array}$ & 294 & 87 & 2 & 9 & 30 & 1 & 56 & 5 & 4 & 32 & -- & 3 & -- & 1 & -- & 64 & -- \\
\hline Splintered piece & 604 & 217 & 7 & 20 & 70 & 6 & 136 & 22 & 29 & 69 & 2 & 4 & 1 & 8 & -- & 13 & -- \\
\hline Flake core & 302 & 67 & 4 & 9 & 50 & -- & 58 & 3 & 8 & 45 & 2 & 14 & 3 & 13 & 4 & 22 & -- \\
\hline Prismatic blade core & 68 & 10 & -- & -- & 1 & -- & 4 & 1 & -- & 5 & -- & -- & -- & -- & -- & 47 & -- \\
\hline $\begin{array}{l}\text { Prismatic bladelet } \\
\text { core }\end{array}$ & 67 & 21 & 1 & 2 & 5 & -- & 12 & 1 & -- & 16 & -- & -- & -- & -- & -- & 9 & -- \\
\hline Pyramidal blade core & 18 & 5 & 1 & -- & 2 & -- & 2 & -- & -- & 2 & -- & -- & -- & -- & -- & 6 & -- \\
\hline $\begin{array}{l}\text { Pyramidal bladelet } \\
\text { core }\end{array}$ & 213 & 81 & 4 & 8 & 20 & 1 & 45 & 3 & 8 & 25 & -- & -- & -- & -- & -- & 18 & -- \\
\hline $\begin{array}{l}\text { Mixed flake/blade } \\
\text { core }\end{array}$ & 9 & 2 & -- & -- & -- & 1 & 3 & -- & -- & 2 & -- & 1 & -- & -- & -- & -- & -- \\
\hline $\begin{array}{l}\text { Mixed flake/bladelet } \\
\text { core }\end{array}$ & 317 & 106 & 3 & 20 & 62 & 1 & 82 & 14 & 8 & 21 & -- & -- & -- & -- & -- & -- & -- \\
\hline $\begin{array}{l}\text { Mixed blade/bladelet } \\
\text { core }\end{array}$ & 7 & 1 & -- & -- & -- & -- & 4 & -- & 1 & 1 & -- & -- & -- & -- & -- & -- & -- \\
\hline $\begin{array}{l}\text { Mixed core } \mathrm{w} / \\
\text { unspecified } \\
\text { composition }\end{array}$ & 132 & 44 & 1 & -- & 10 & -- & 11 & 1 & -- & 20 & -- & -- & -- & -- & -- & 45 & -- \\
\hline Total & 162090 & 8295 & 342 & 926 & 3963 & 94 & 5024 & 459 & 778 & 3554 & 87 & 485 & 189 & 550 & 102 & 8870 & 128372 \\
\hline
\end{tabular}


Table 2. Lithic Tool Counts by Raw Material Type.

Geographically known lithic toolstones are abbreviated as follows: Barrika (BAR), Bidache (BID), Chalosse (CHAL), Llaranza (LLAR), OjoGuareña (OJO), Sonabia (SON), Treviño (TREV), and Urbasa (URB). All other lithic toolstones are abbreviated as follows: other flints (OF), limestones (LIME),

lutites/mudstones (MUD), quartzes and calcites (QC), quartzite (QTZ), other toolstones (OTHER), unknown stones (UNK) and microdebitage (MD). Tool types were classified using the de SonnevilleBordes and Perrot Upper Paleolithic tool typology.

\begin{tabular}{|c|c|c|c|c|c|c|c|c|c|c|c|c|c|c|c|c|}
\hline Tool Type & Total & BAR & BID & CHAL & LLAR & OJO & SON & TREV & URB & OF & LIME & MUD & QC & QTZ & OTHER & UNK \\
\hline Simple endscraper & 22 & 5 & 2 & & 4 & & 5 & & 2 & & & & & & & 4 \\
\hline Atypical endscraper & 37 & 12 & 2 & 1 & 3 & 1 & 7 & 1 & & 4 & 1 & & & 1 & & 4 \\
\hline Double endscraper & 5 & 2 & & 1 & & & 1 & & & & & & & & & 1 \\
\hline Ogival endscraper & 6 & 4 & & & & & 2 & & & & & & & & & \\
\hline $\begin{array}{l}\text { Endscraper on } \\
\text { retouched flake/blade }\end{array}$ & 6 & 2 & & & 1 & & & & & 1 & & & & & & 2 \\
\hline $\begin{array}{l}\text { Endscraper on } \\
\text { Aurignacian blade }\end{array}$ & 1 & 1 & & & & & & & & & & & & & & \\
\hline Endscraper on flake & 22 & 6 & & & 5 & & 2 & & 1 & 2 & & & 1 & & & 5 \\
\hline Circular endscraper & 2 & 1 & & & 1 & & & & & & & & & & & \\
\hline $\begin{array}{l}\text { Unguiform (thumbnail) } \\
\text { endscraper }\end{array}$ & 19 & 9 & & & 1 & & 2 & & 1 & 3 & & 1 & & & & 2 \\
\hline Carinated endscraper & 39 & 16 & 1 & 1 & 6 & & 6 & 1 & 2 & 3 & & & & & & 3 \\
\hline $\begin{array}{l}\text { Atypical carinated } \\
\text { endscraper }\end{array}$ & 57 & 9 & & 5 & 14 & & 14 & 3 & 2 & 7 & & & & & & 3 \\
\hline Thick nosed endscraper & 32 & 8 & & & 7 & 1 & 6 & 2 & & 1 & & 1 & & & & 6 \\
\hline $\begin{array}{l}\text { Flat nosed/shouldered } \\
\text { endscraper }\end{array}$ & 9 & 3 & & & & & 2 & & 1 & 1 & & & & & & 2 \\
\hline Nucleiform endscraper & 358 & 114 & 2 & 21 & 58 & 2 & 81 & 15 & 9 & 25 & & 1 & & 1 & & 29 \\
\hline Rabot/Plane & 1 & 1 & & & & & & & & & & & & & & \\
\hline Endscraper-burin & 22 & 7 & & 3 & & & 5 & 1 & & 3 & & & & & & 3 \\
\hline Burin-truncated piece & 4 & 1 & & & 1 & & 2 & & & & & & & & & \\
\hline $\begin{array}{l}\text { Perforator-truncated } \\
\text { piece }\end{array}$ & 5 & 2 & & & 1 & & & & & 1 & & & & & & 1 \\
\hline Perforator-endscraper & 17 & 4 & & & 3 & & 7 & 1 & 1 & 1 & & & & & & \\
\hline
\end{tabular}




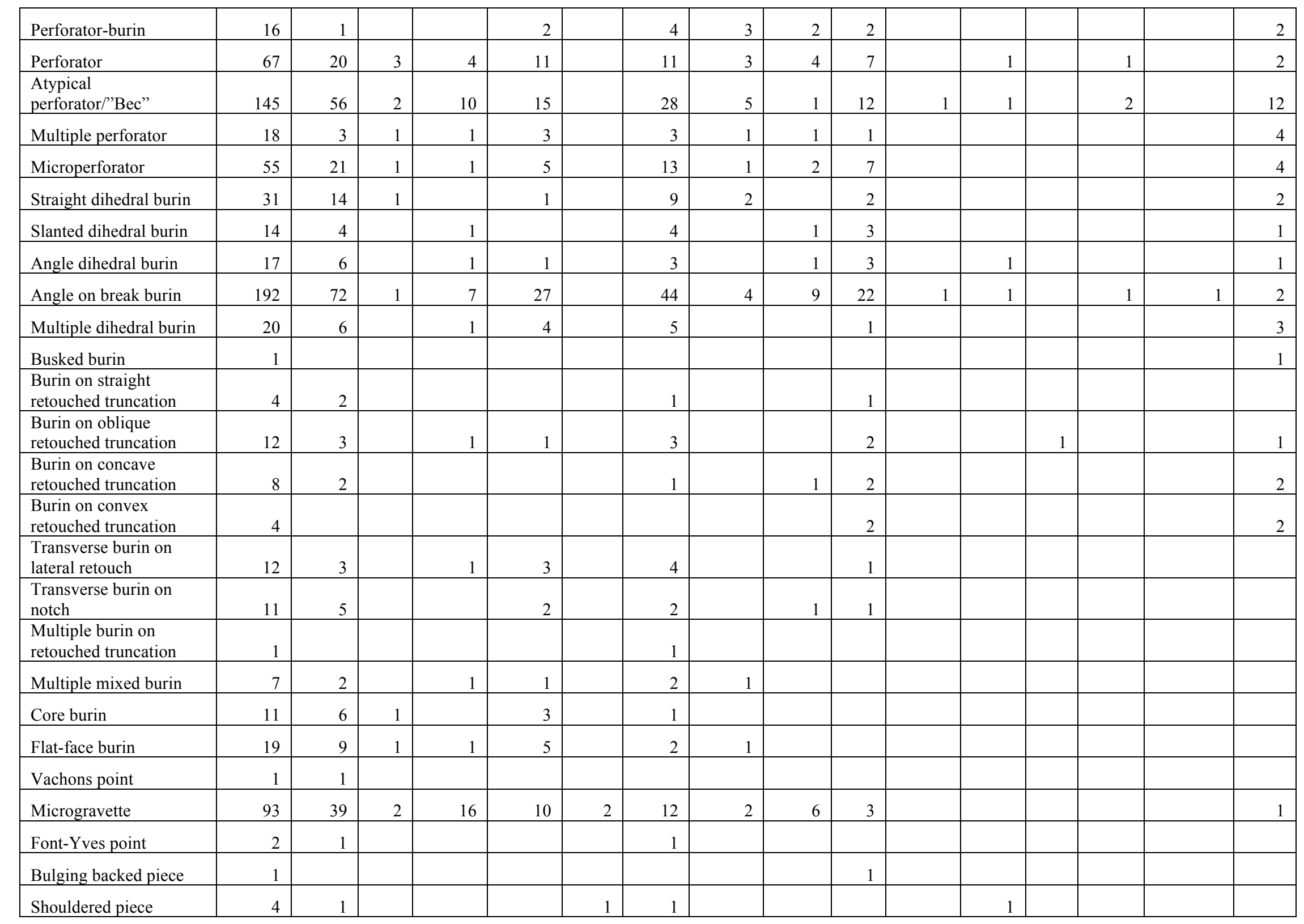




\begin{tabular}{|c|c|c|c|c|c|c|c|c|c|c|c|c|c|c|c|c|}
\hline $\begin{array}{l}\text { Completely backed } \\
\text { blade }\end{array}$ & 21 & 8 & 1 & 2 & & & 4 & & & 3 & & 1 & & & & 2 \\
\hline Partially backed blade & 7 & 1 & & & & & 1 & & & 1 & & & & & & 4 \\
\hline Straight truncated piece & 26 & 7 & & 3 & 3 & & 6 & 1 & & 4 & & 1 & & & & 1 \\
\hline Oblique truncated piece & 62 & 16 & 2 & 3 & 10 & & 14 & 3 & 5 & 7 & & & & 1 & & 1 \\
\hline Concave truncated piece & 4 & 2 & & 1 & & & 1 & & & & & & & & & \\
\hline Convex truncated piece & 5 & 4 & & & & & 1 & & & & & & & & & \\
\hline Bitruncated piece & 2 & & & 1 & & & & & 1 & & & & & & & \\
\hline $\begin{array}{l}\text { Continuously retouched } \\
\text { piece (CRP)-1 }\end{array}$ & 338 & 99 & 6 & 19 & 51 & 1 & 77 & 5 & 10 & 28 & & 5 & 1 & 6 & & 30 \\
\hline $\begin{array}{l}\text { Continuously retouched } \\
\text { piece (CRP)-2 }\end{array}$ & 43 & 14 & 2 & 1 & 2 & 1 & 7 & 1 & & 5 & & 2 & & 1 & & 7 \\
\hline Solutrean unifacial point & 2 & 1 & & & & & 1 & & & & & & & & & \\
\hline $\begin{array}{l}\text { Solutrean laurel leaf } \\
\text { point }\end{array}$ & 1 & & & & & & & & & & & & & & & 1 \\
\hline $\begin{array}{l}\text { Solutrean willow leaf } \\
\text { point }\end{array}$ & 1 & & & & & & & & & 1 & & & & & & \\
\hline Pick & 1 & & & & & & & & & & & & & 1 & & \\
\hline Notch & 454 & 128 & 11 & 23 & 73 & 2 & 86 & 10 & 15 & 48 & 1 & 17 & 1 & 22 & 2 & 15 \\
\hline Denticulate & 228 & 53 & 6 & 3 & 25 & 4 & 33 & 5 & 8 & 18 & 3 & 28 & & 21 & 2 & 19 \\
\hline Splintered piece & 519 & 188 & 5 & 20 & 53 & 5 & 126 & 19 & 22 & 60 & 1 & 3 & 1 & 8 & & 8 \\
\hline Sidescraper & 60 & 12 & 1 & 1 & 16 & & 11 & & 2 & 4 & & 5 & & 4 & 2 & 2 \\
\hline Raclette & 13 & 4 & 1 & & 1 & & 4 & 1 & 1 & & & & & & & 1 \\
\hline Triangle & 18 & 4 & 1 & 2 & 4 & & 4 & 1 & 1 & 1 & & & & & & \\
\hline Trapeze & 3 & 1 & & & & & 1 & & & 1 & & & & & & \\
\hline Circle segment & 30 & 13 & & 1 & 4 & & 5 & & 2 & 1 & & & & & & 4 \\
\hline Truncated bladelet & 55 & 16 & 2 & 5 & 10 & & 11 & 2 & 2 & 6 & & & & & & 1 \\
\hline Backed bladelet & 1200 & 466 & 12 & 62 & 137 & 6 & 206 & 18 & 40 & 160 & & & 5 & & & 88 \\
\hline $\begin{array}{l}\text { Truncated backed } \\
\text { bladelet }\end{array}$ & 89 & 26 & & 5 & 16 & & 21 & 3 & 2 & 13 & & & & & & 3 \\
\hline $\begin{array}{l}\text { Denticulated backed } \\
\text { bladelet }\end{array}$ & 14 & 6 & 1 & & 1 & & 4 & & & 1 & & & & & & 1 \\
\hline Denticulated bladelet & 21 & 10 & & & 1 & & 3 & & 1 & 5 & & & & & & 1 \\
\hline
\end{tabular}




\begin{tabular}{|c|c|c|c|c|c|c|c|c|c|c|c|c|c|c|c|c|}
\hline Notched bladelet & 38 & 11 & & 2 & 5 & & 7 & 1 & 1 & 9 & & & & & 1 & 1 \\
\hline $\begin{array}{l}\text { Retouched (Dufour) } \\
\text { bladelet }\end{array}$ & 316 & 130 & 2 & 27 & 48 & 2 & 66 & 8 & 7 & 23 & & & 1 & & & 2 \\
\hline Azilian point & 2 & 2 & & & & & & & & & & & & & & \\
\hline Diverse & 350 & 118 & 7 & 16 & 46 & 5 & 88 & 6 & 15 & 30 & 2 & 6 & & 4 & & 7 \\
\hline TOTAL & 5353 & 1824 & 80 & 275 & 705 & 33 & 1085 & 131 & 183 & 554 & 10 & 76 & 11 & 74 & 8 & 304 \\
\hline
\end{tabular}


Table 3. Summary of Cores from Level 17.

Geographically known lithic toolstones are abbreviated as follows: Barrika (BAR), Bidache (BID), Chalosse (CHAL), Llaranza (LLAR), OjoGuareña (OJO), Sonabia (SON), Treviño (TREV), and Urbasa (URB). All other lithic toolstones are abbreviated as follows: other flints (OF), lutites/mudstones (MUD, quartzite (QTZ), and unknown stones (UNK). In the reduction scars subsection of this table, mixed cores are defined as those with both flake and bladelet removals. Data are presented as counts for each type listed. *Indicates that one of these was a blade removal.

\begin{tabular}{|c|c|c|c|c|c|c|c|c|c|c|c|c|c|}
\hline Core Type & BAR & BID & CHAL & LLAR & OJO & SON & TREV & URB & OF & QTZ & MUD & UNK & Total \\
\hline Prismatic & 9 & -- & -- & 2 & 1 & 7 & -- & -- & 3 & -- & -- & 3 & 25 \\
\hline Semi-prismatic & 15 & 3 & 2 & 9 & -- & 7 & 2 & 1 & 9 & -- & 1 & 10 & 59 \\
\hline Pyramidal & 29 & 2 & 2 & 12 & -- & 16 & 6 & 2 & 10 & -- & -- & 17 & 96 \\
\hline Semi-pyramidal & 48 & 2 & 3 & 25 & 1 & 27 & 4 & 7 & 8 & -- & 1 & 26 & 152 \\
\hline Globular & 24 & -- & 2 & 12 & -- & 21 & 1 & 1 & 11 & 1 & 1 & 10 & 84 \\
\hline Semi-globular & 1 & -- & -- & -- & -- & 1 & -- & -- & -- & -- & -- & -- & 2 \\
\hline Piece esquillee & 4 & -- & -- & 1 & -- & 4 & -- & 1 & -- & -- & -- & 2 & 12 \\
\hline Core on flake & 25 & 1 & 6 & 8 & -- & 11 & 0 & 2 & 11 & -- & 2 & 11 & 78 \\
\hline Tested cobble & 6 & -- & -- & 1 & -- & 2 & -- & -- & 1 & -- & -- & 3 & 13 \\
\hline Amorphous & 24 & 1 & 1 & 9 & 1 & 11 & 2 & 1 & 4 & 1 & 1 & 8 & 64 \\
\hline Semi-carinated & 10 & -- & 2 & 5 & -- & 5 & 2 & 1 & 7 & -- & -- & 2 & 34 \\
\hline Chunk with removal(s) & 9 & -- & 2 & 1 & 1 & 6 & -- & 1 & 5 & -- & -- & 3 & 28 \\
\hline Sausage slice & 3 & -- & -- & 2 & -- & -- & -- & -- & -- & -- & -- & -- & 5 \\
\hline Flake & 1 & -- & -- & -- & -- & -- & -- & -- & -- & -- & -- & -- & 1 \\
\hline Broken cobble & 1 & -- & -- & -- & -- & 1 & -- & -- & -- & -- & -- & -- & 2 \\
\hline Discoidal & 2 & -- & -- & -- & -- & -- & -- & -- & 2 & -- & -- & -- & 4 \\
\hline Semi-discoidal & 1 & -- & -- & 1 & -- & -- & -- & -- & -- & -- & -- & -- & 2 \\
\hline Core on blade & -- & -- & -- & -- & -- & 1 & -- & -- & -- & -- & -- & -- & 1 \\
\hline Mixed types & 7 & -- & 3 & 4 & -- & 5 & 1 & 2 & 3 & -- & -- & 10 & 35 \\
\hline Total & 220 & 9 & 23 & 92 & 4 & 125 & 18 & 19 & 74 & 2 & 6 & 105 & 697 \\
\hline Cortical & 96 & 3 & 7 & 35 & 2 & 53 & 7 & 9 & 24 & 2 & 4 & 35 & \\
\hline
\end{tabular}

Size

Avg. Length

Length Range

Avg. Width

Width Range

Avg. Thickness

Thickness Range

$\begin{array}{llllllllllll}24 & 23 & 22 & 25 & 23 & 24 & 26 & 22 & 25 & 59 & 39 & 24 \\ 11-58 & 16-31 & 15-30 & 14-46 & 19-27 & 9-49 & 15-38 & 13-32 & 12-51 & 34-84 & 25-69 & 7-54 \\ 19 & 17 & 18 & 19 & 19 & 19 & 19 & 19 & 19 & 51 & 31 & 19 \\ 6-41 & 11-26 & 12-27 & 12-35 & 16-25 & 7-49 & 12-32 & 6-49 & 11-41 & 30-71 & 16-63 & 8-52 \\ 13 & 12 & 13 & 14 & 13 & 14 & 14 & 12 & 13 & 33 & 21 & 13 \\ 7-40 & 8-20 & 8-22 & 8-25 & 10-16 & 4-136 & 9-19 & 3-22 & 5-28 & 17-48 & 7-56 & 4-25\end{array}$


Table 3, Continued

\begin{tabular}{|c|c|c|c|c|c|c|c|c|c|c|c|c|}
\hline Core Type & BAR & BID & CHAL & LLAR & OJO & SON & TREV & URB & $\mathbf{O F}$ & QTZ & MUD & UNK \\
\hline \multicolumn{13}{|l|}{ Polarity } \\
\hline Unipolar & 93 & 3 & 13 & 38 & 3 & 44 & 7 & 12 & 30 & -- & 2 & 47 \\
\hline Bipolar & 53 & 4 & 4 & 18 & 1 & 35 & 7 & 3 & 20 & -- & 2 & 30 \\
\hline Multipolar & 70 & 2 & 6 & 35 & -- & 45 & 4 & 4 & 24 & 2 & 2 & 28 \\
\hline Unknown & 4 & -- & -- & 1 & -- & 1 & -- & -- & -- & -- & -- & -- \\
\hline \multicolumn{13}{|l|}{ Edge Regularization } \\
\hline Yes & 29 & 1 & 6 & 12 & -- & 22 & 5 & 3 & 6 & -- & 1 & 16 \\
\hline No & 157 & 8 & 15 & 67 & 4 & 88 & 12 & 14 & 60 & 2 & 4 & 78 \\
\hline Yes? & 3 & -- & -- & 4 & -- & 3 & 1 & -- & 1 & -- & -- & 2 \\
\hline No? & -- & -- & 1 & -- & -- & 1 & -- & -- & -- & -- & -- & -- \\
\hline Endscraper & 29 & -- & 1 & 8 & -- & 10 & -- & 2 & 7 & -- & 1 & 9 \\
\hline Unknown & 2 & -- & -- & 1 & -- & 1 & -- & -- & -- & -- & -- & -- \\
\hline \multicolumn{13}{|l|}{ Reduction Scars } \\
\hline Mixed cores & 173 & 9 & 19 & 78 & 4 & 99 & 16 & 11 & 52 & -- & 3 & 87 \\
\hline Bladelet scars present & 187 & 9 & 22 & 81 & 4 & 113 & 16 & 13 & 61 & -- & 4 & 94 \\
\hline Flake scars present & 206 & 9 & 20 & 89 & 4 & 111 & 18 & 17 & 65 & 2 & 5 & 98 \\
\hline 1-3 bladelet scars & 113 & 7 & 14 & $59 *$ & 3 & 71 & 9 & 8 & 41 & -- & 3 & 60 \\
\hline 4-7 bladelet scars & 69 & 2 & 8 & 22 & 1 & 40 & 7 & 5 & 20 & -- & 1 & 30 \\
\hline $8-10$ bladelet scars & 5 & -- & -- & -- & -- & 2 & -- & -- & -- & -- & -- & 4 \\
\hline 1-3 flake scars & 95 & 5 & 12 & 34 & 4 & 44 & 8 & 7 & 21 & -- & 2 & 42 \\
\hline 4-7 flake scars & 98 & 4 & 6 & 45 & -- & 55 & 8 & 8 & 36 & 1 & 2 & 50 \\
\hline $8-10$ flake scars & 12 & -- & 1 & 9 & -- & 11 & 2 & 2 & 6 & -- & -- & 5 \\
\hline 11-13 flake scars & -- & -- & 1 & 1 & -- & 1 & -- & -- & 2 & -- & 1 & 1 \\
\hline 14-16 flake scars & 1 & -- & -- & -- & -- & -- & -- & -- & -- & 1 & -- & -- \\
\hline
\end{tabular}


Table 4. Summary of microwear traces observed in the El Mirón Level 17 sample. Secondary traces are abbreviated as follows: fissures $(F)$, edge abrasion $(E)$, metallic marks $(M)$, bone scraping $(B)$, possible (?) antler scraping $(A S)$, and green wood scraping $(W)$.

\begin{tabular}{|c|c|c|c|c|c|c|c|}
\hline & \multirow[t]{2}{*}{ Primary Trace } & \multicolumn{6}{|c|}{ Secondary Traces } \\
\hline & & $\mathrm{F}$ & $\mathrm{E}$ & $\mathrm{M}$ & B & $\mathrm{AS}$ & $\mathrm{W}$ \\
\hline $\begin{array}{l}\text { Not Used } \\
\text { Percussion }\end{array}$ & 16 & -- & -- & -- & -- & -- & -- \\
\hline Hard & 59 & 6 & 1 & 8 & 1 & 1 & -- \\
\hline Soft & 2 & 1 & -- & -- & -- & -- & -- \\
\hline Indeterminable & 10 & -- & -- & -- & -- & -- & 1 \\
\hline Fissures & 11 & -- & -- & -- & -- & -- & -- \\
\hline Edge Abrasion & 2 & -- & -- & -- & -- & -- & -- \\
\hline Metallic Marks & 1 & -- & -- & -- & -- & -- & -- \\
\hline
\end{tabular}


Cores, Core-Scrapers, and Bladelet Production during the Lower Magdalenian Occupations of El Mirón Cave, Cantabrian Spain

Lawrence G. Straus ${ }^{1}{ }^{2}$, Lisa M. Fontes ${ }^{1 *}$, Rafael Domingo ${ }^{3}$, Manuel R. González Morales ${ }^{2}$

${ }^{1}$ Department of Anthropology, MSC01 1049, University of New Mexico, Albuquerque, NM 87131-0001 USA

${ }^{2}$ Instituto Internacional de Investigaciones Prehistóricas de Cantabria, Universidad de Cantabria, Avda.de los Castros s/n, 39005 Santander, Spain

${ }^{3}$ Depto.de Ciencias de la Antigüedad, Universidad de Zaragoza, Plaza Constitución s/n, 22001

Zaragoza, Spain

*Corresponding Author (fontes.lisa.marie@gmail.com) 


\section{Vasco-Cantabria and Gascony}

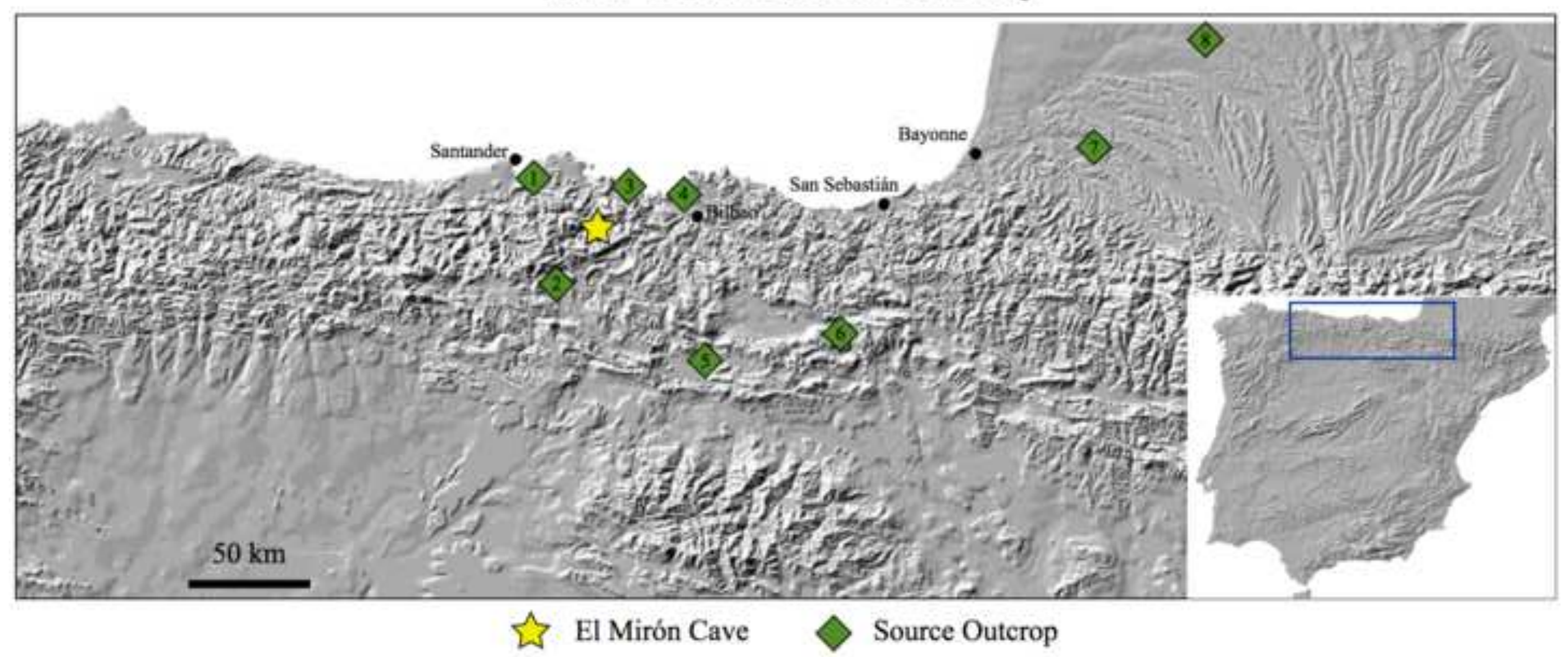




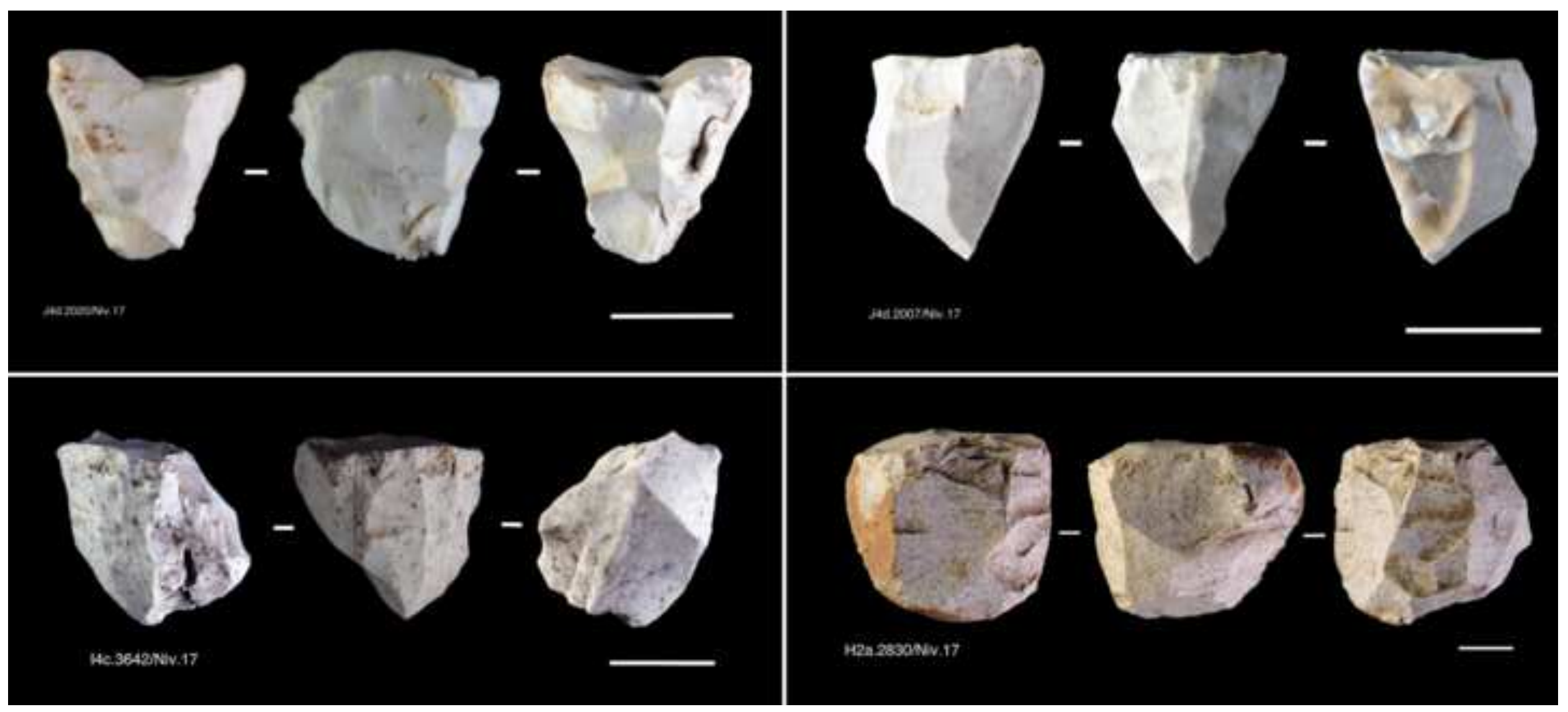




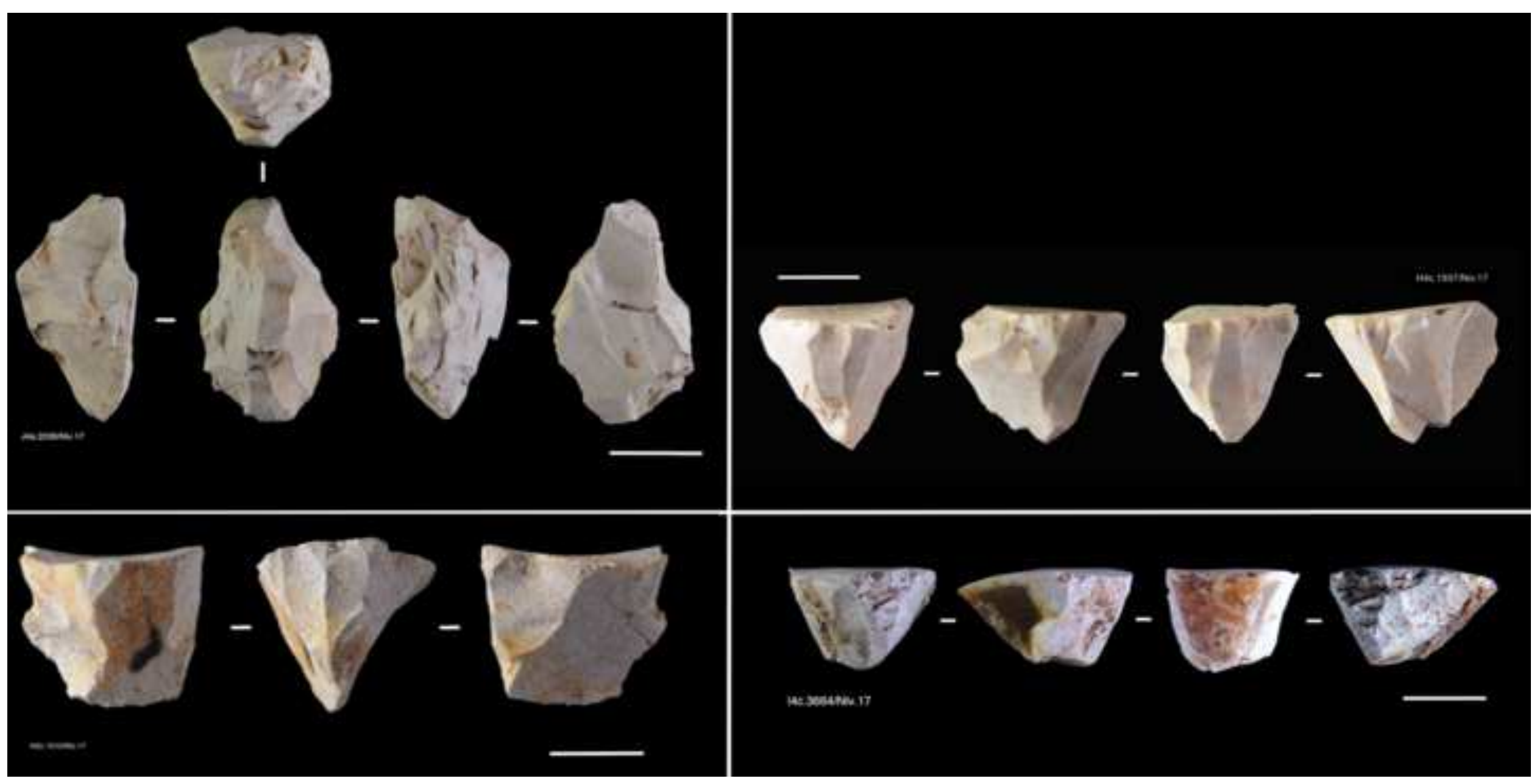




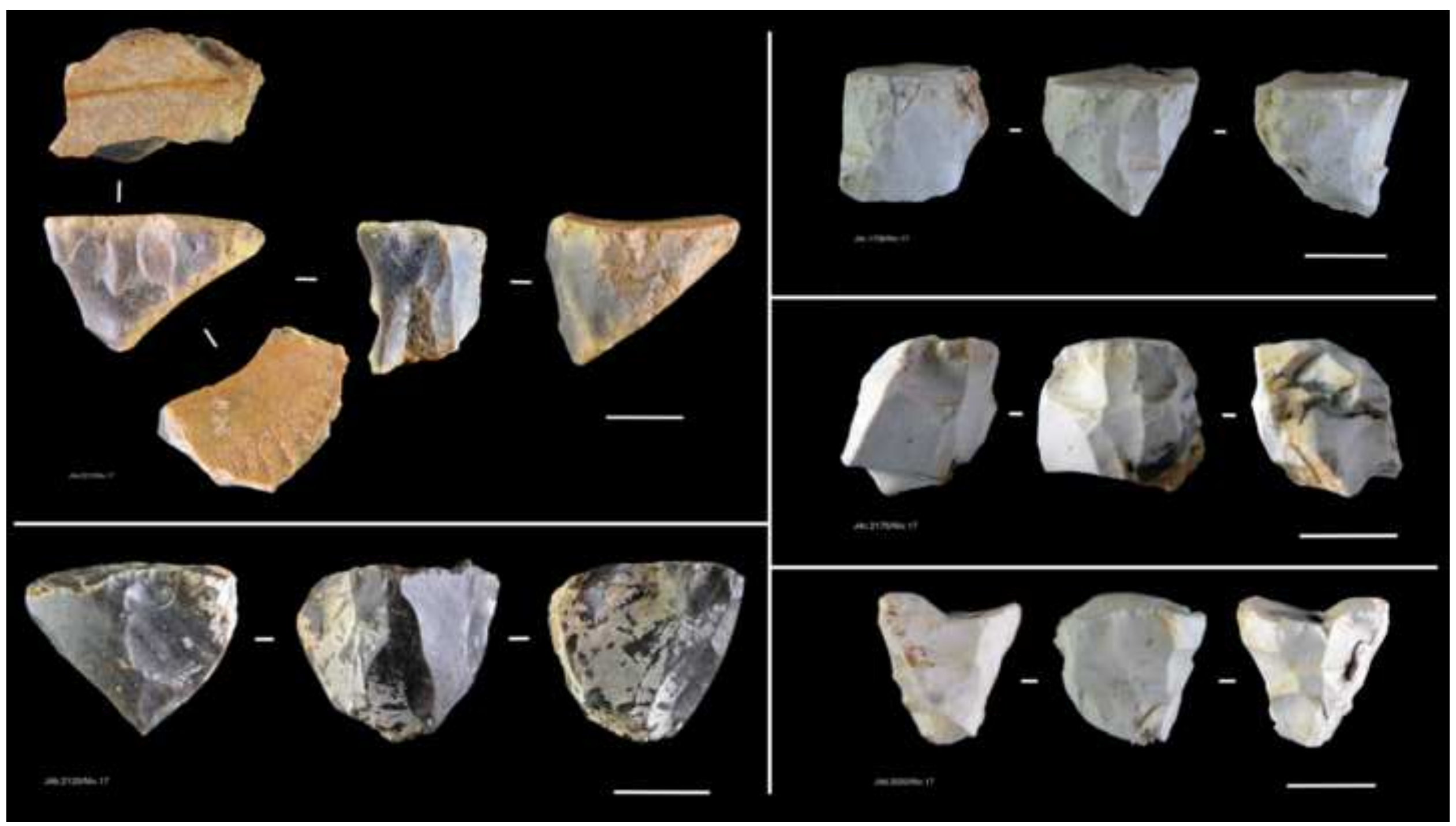




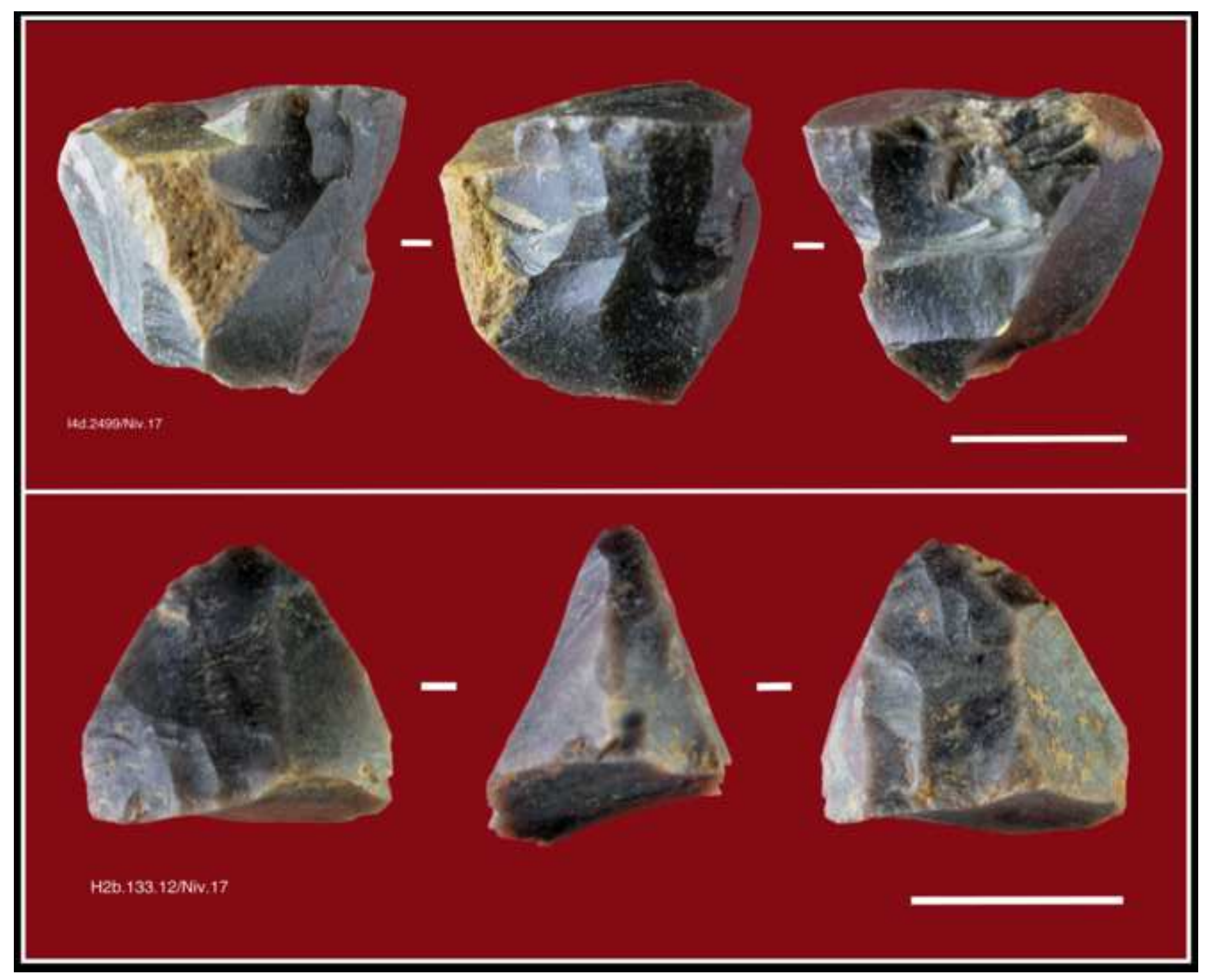


Click here to download Non-colour figure Fig 6.tiff $\underline{\underline{\underline{ }}}$

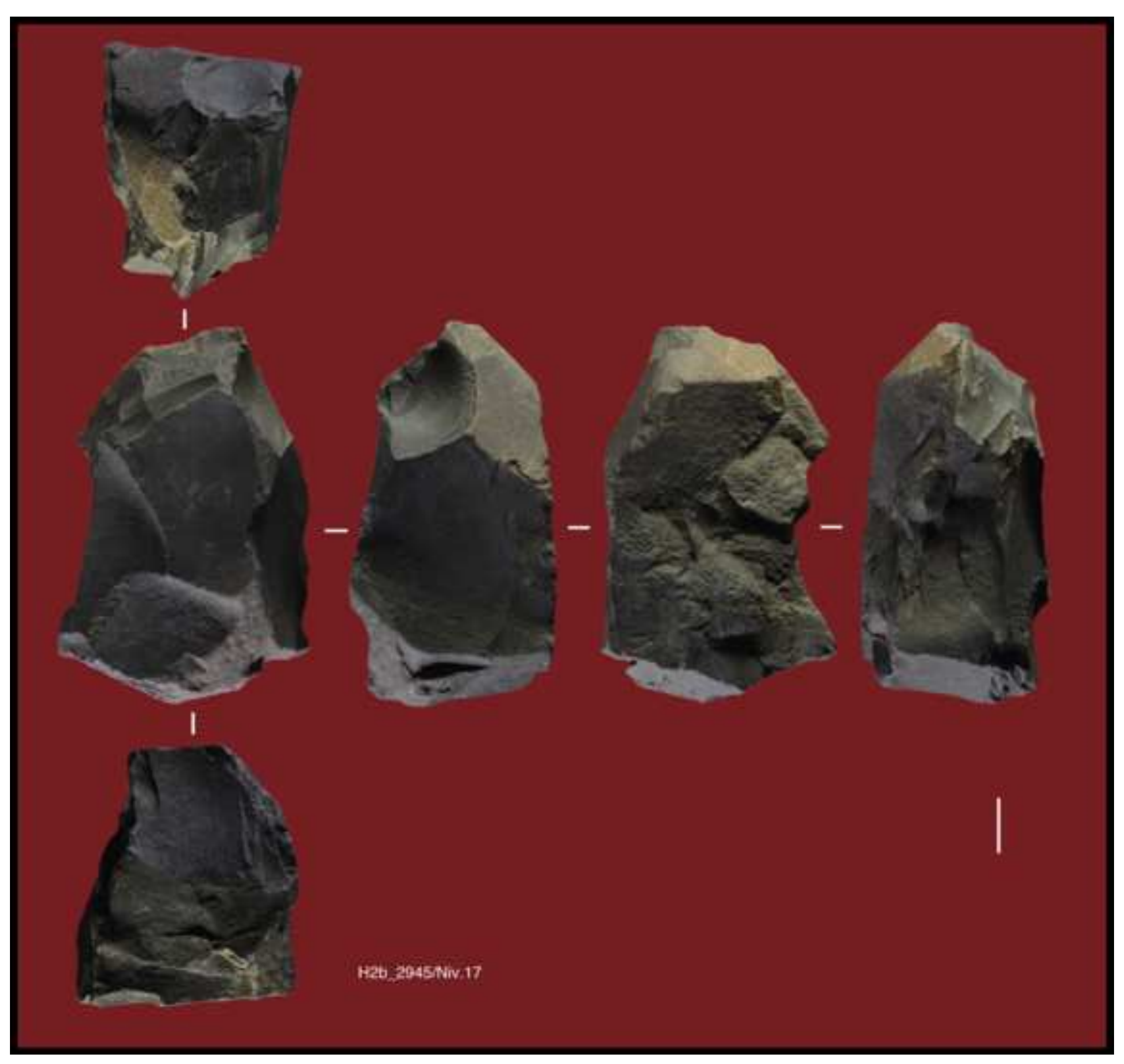




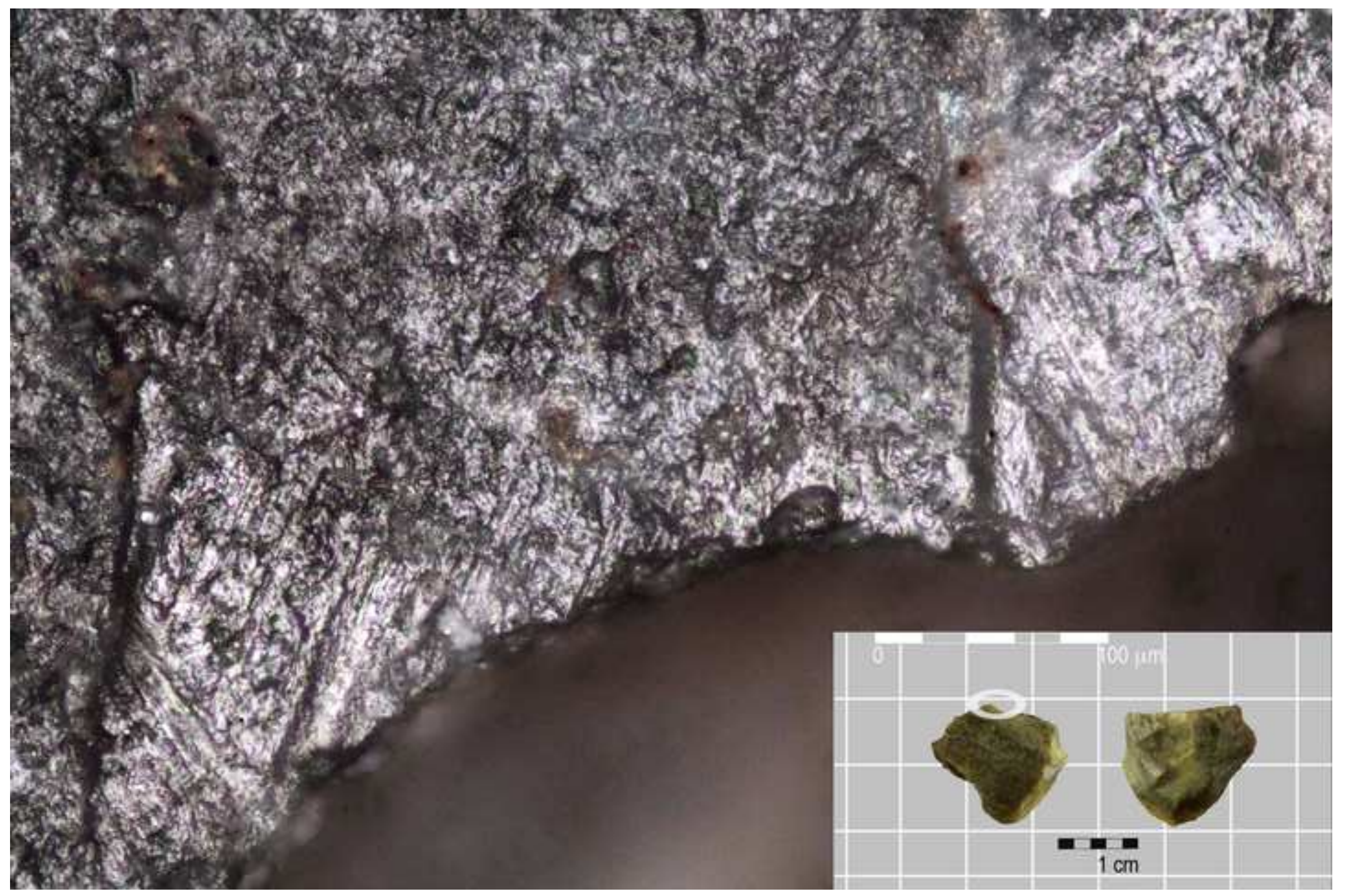




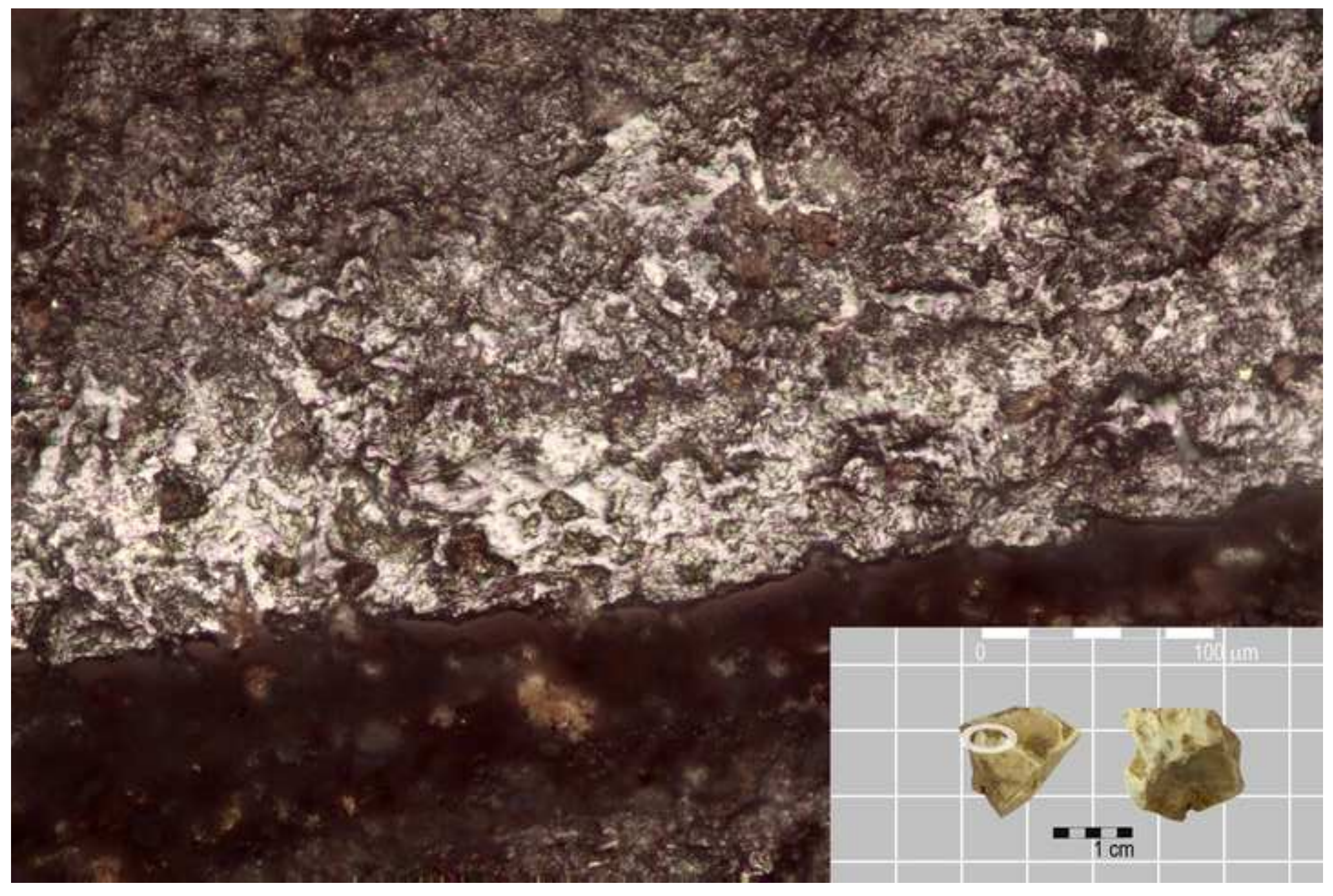




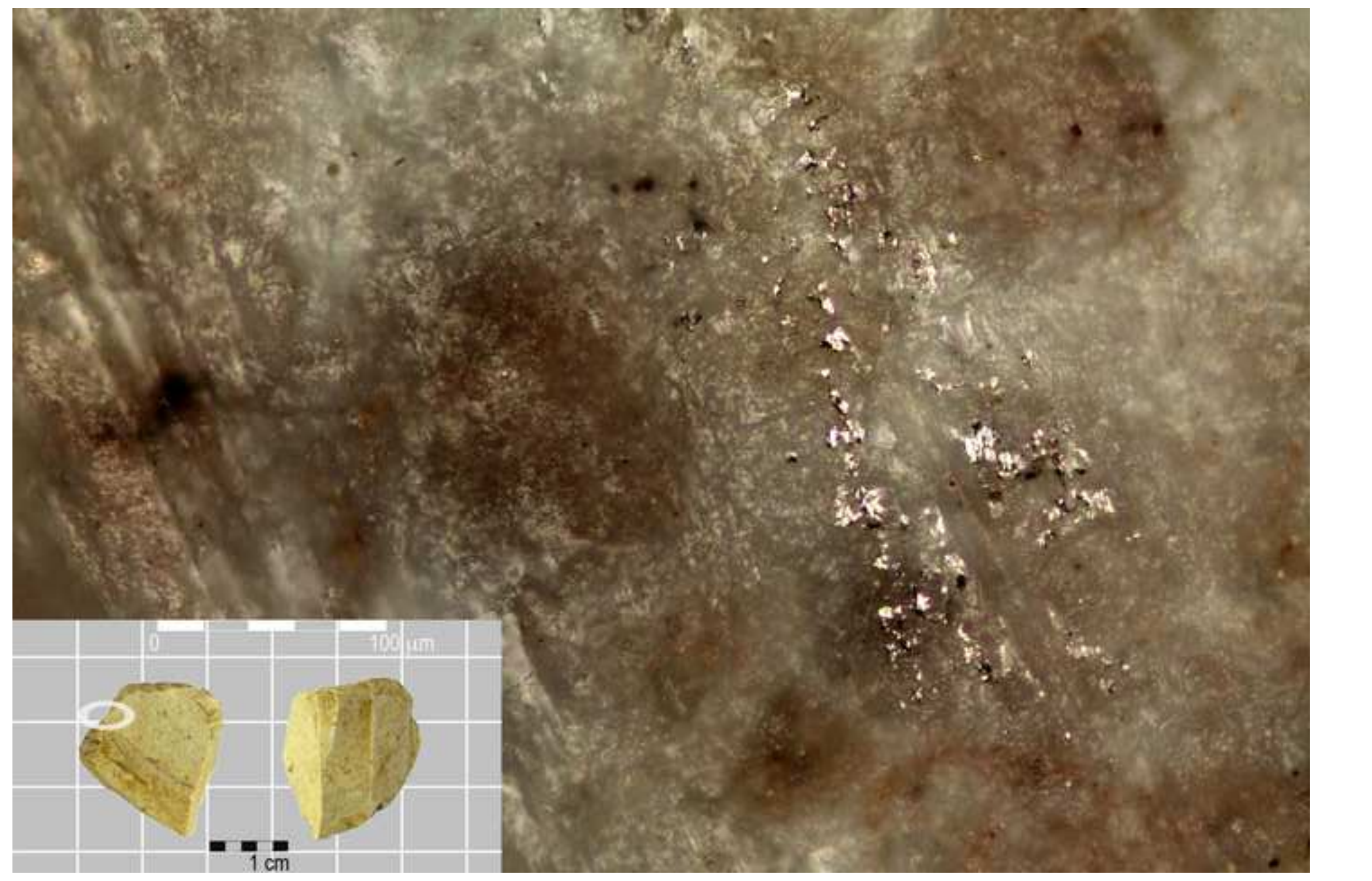

$1 \mathrm{~cm}$ 